\title{
„Komuniści (nie) mają ojczyzny...” Wanda Wasilewska jako polska (anty)bohaterka narodowa ${ }^{1}$
}

\author{
Agnieszka Mrozik
}

\begin{abstract}
Abstrakt: Autorka analizuje powstające w różnych okresach historycznych biografie Wandy Wasilewskiej. Usiłuje odtworzyć mechanizmy konstruowania figury komunistki w polskim dyskursie publicznym, zbadać, jak funkcjonowała ona w społecznym odbiorze, a także ustalić, jak zmieniało się jej znaczenie w procesie przemian historycznych i kulturowych. Autorka pokazuje, że tworzenie spójnej biografii jednostki - szczególnie jednostki ważnej w historii danej zbiorowości - dokonuje się w odpowiedzi na tożsamościowe poszukiwania wspólnoty: służy wytworzeniu zbiorowej biografii jako koherentnej całości. Zwraca uwagę, że pisanie biografii Wasilewskiej jako komunistki było i wciąż jest swoistym „wytwarzaniem komunizmu” w Polsce. Komunizm zaś w szerokim planie jest ważnym - jeśli nie najważniejszym w ostatnich dziesięcioleciach - komponentem polskiej zbiorowej tożsamości.

Wyrażenia kluczowe: komunizm, biografia, patriotyzm, tożsamość, naród, analiza dyskursu, Wanda Wasilewska
\end{abstract}

Wanda Wasilewska (1905-1964) to ważna bohaterka „komunistycznego panteonu”, która po 1989 roku została w zbiorowej pamięci i historii „zdegradowana”: „odebrano” jej patronat nad ulicami i instytucjami państwowymi, jej książki usunięto z list lektur i wycofano z bibliotek szkolnych. Z patronki Polskiej Rzeczypospolitej Ludowej i narodowej wieszczki przekształciła się w symbol zdrady i degeneracji peerelowskich elit i całego systemu. Jej losy obrazują jednak nie tylko pewne prawidłowości polityki historycznej, sprowadzające się w wielkim uproszczeniu do wymiany elit i symboli (Čolović, 2001). Historia życia i aktywności Wasilewskiej, a szczególnie jej dzieje pośmiertne (swoiste „życie po życiu”, jakie wyłania się z różnych dokumentów i opracowań historycznych, wspomnień, biografii i tekstów autobiograficznych, zarówno tych opublikowanych przed 1989 rokiem, jak i później), odsłaniają ogromną i trwającą nieprzerwanie „pracę dyskursów”, które produkując „ja” mocno osadzone w określonym kontekście społecznym, politycznym, kulturowym i ekonomicznym, projektują także lekturę tego „ja”.

Zadanie, jakie sobie stawiam w niniejszym tekście, nie polega na dochodzeniu „prawdy” o Wandzie Wasilewskiej (ani o komunistkach czy komunizmie). Pragnę raczej pokazać, jak to się stało, że Wasilewska z racji zaszyfrowanych w jej postaci (życiu, twórczości literackiej i aktywności politycznej) znaczeń płciowych, seksualnych, narodowych i klasowych oraz ambiwalencji z nimi związanych stała się „żywą alegorią” komunizmu: nie tylko sprawowała, ale i personifikowała ten rodzaj władzy, o której niekiedy z uwielbieniem,

1 Artykuł jest częściowo zmienioną i skróconą wersją artykułu, który ukazał się pod tytułem „Wanda, co wolała Rusa”. Wytwarzanie (biografii) komunistki - wytwarzanie (tożsamości) narodu w książce PRL - życie po życiu (Chmielewska, Mrozik, \& Wołowiec, 2013). 
niekiedy ze strachem i obrzydzeniem wypowiadali się i wypowiadają „świadkowie epoki” oraz jej badacze. Interesuje mnie, jak to się stało, że ta decyzyjna, równa mężczyznom (a niekiedy wyższa od nich rangą) kobieta raz uosabiała emancypacyjny wymiar władzy komunistycznej, a innym razem - jako „zaufana diabła” (Stalina) - jej patologiczny, obcy charakter. Zastanawiam się, w jaki sposób z określonego materiału - pewnych zdarzeń z życia i działalności Wasilewskiej, bądź wyciąganych na wierzch, bądź ukrywanych, raz akcentowanych, a innym razem chowanych w cieniu - „wykrawano” postać to zbawicielki ojczyzny, to jej najpodlejszej zdrajczyni.

Kwestia patriotyzmu i narodowej (samo)identyfikacji Wasilewskiej-komunistki jest dla mnie kluczowa: w PRL kreowano ją na wzór albo internacjonalistki, albo żarliwej patriotki, albo ikony łączącej cechy rewolucjonistki i bohaterki narodowej; po 1989 roku zdezawuowano z kolei jej postać i zaliczono w poczet „wielkich zdrajców” narodu (por. Koper, 2012). Interesujące wydaje mi się pokazanie, w jaki sposób „wytwarzano/ wytwarza się Wasilewską" jako polską (anty)bohaterkę narodową, stosując wobec niej symboliczną przemoc polegającą na zawłaszczaniu jej głosu bądź, przeciwnie, odmawianiu go jej, wyrywaniu jej wypowiedzi i zachowań z kontekstu lub wpisywaniu ich w obcy kontekst, pomijaniu ewolucji jej poglądów albo też „specyficznej” ich (re)konstrukcji itd. Równie interesujące wydaje mi się jednak wskazanie miejsc oporu Wasilewskiej przeciwko różnym przemocowym praktykom stosowanym wobec niej. Ujawniają się one tam, gdzie oficjalne wizerunki pisarki nie przystają do siebie, odsłaniając rozbieżności lub tylko przesunięcia nakreślonych linii, białe plamy lub zaciemnienia; czyli tam, gdzie wszystko wydawało/ wydaje się klarowne.

\section{Biograficzna iluzja}

Zasadniczy problem z pisaniem o takich osobach, jak Wanda Wasilewska, wiąże się z tym, że ich życie i działalność podlegają niezwykle silnej symbolizacji. W jednym z listów do matki Wasilewska pisała: „Jeśli kiedyś zdecyduję się pisać pamiętniki, to będę miała jedną trudność, jak w jednym życiu pomieścić to wszystko, co w nim było" (cyt. za: Syzdek, 1980, s. 8). Wydaje się, że jej biografowie i biografki zrealizowali to zadanie z naddatkiem: opowiadając historię jej życia, uczynili ją symbolem czy też alegorią zjawisk i procesów, w które była uwikłana; rekonstruując jej życiorys, zobrazowali idee, w które była zaangażowana; a obrazując je, przyczynili się do ich uprawomocnienia lub, przeciwnie, odmówienia im racji bytu. Wśród tych idei na plan pierwszy wysuwa się komunizm. Jestem zdania, że „wytwarzanie biografii” Wasilewskiej było i wciąż jest swoistym „wytwarzaniem komunizmu” w Polsce (Hobsbawm \& Ranger, 2008). PRL „przeglądał się” w biografii Wasilewskiej jak w lustrze i szukał w niej to akceptacji (wielkości, słuszności), to sprostowania (autokorekty, mającej mu umożliwić zaadaptowanie do zmieniających się warunków społecznych i politycznych). Popeerelowska współczesność przedstawia z kolei Wasilewską w krzywym zwierciadle, karykaturując w jej osobie całą ideę komunizmu. 
Są dwie dominujące narracje o Wandzie Wasilewskiej: całkowicie różne, wręcz rozłączne, a zarazem komplementarne. Obie roszczą sobie pretensje do pełni - oddania „prawdy” o życiu i działalności pisarki, wyjawienia jej głęboko skrywanych motywacji, naświetlenia osobistych i politycznych powiązań. W pierwszej Wasilewska jest „świętą komunizmu”, „tytanką”, „żołnierzem na froncie spraw wielkich”, w drugiej - „renegatką”, „zbrodniarką”, „boginią zła”. To, co w pierwszej działa na jej korzyść, w drugiej ją obciąża. Zdaniem Pierre’a Bourdieu, takie tworzenie biografii wynika z pokusy od-tworzenia historii życia człowieka jako spójnej całości, projektu pozbawionego sprzeczności, co dokonuje się przez wpisanie życia w gotowe schematy narracyjne. Bourdieu nazywa ten mechanizm „biograficzną iluzją”: rekonstruowanie historii życia jest procesem nadawania mu znaczeń przez biografa, który staje się ich interpretatorem. W tym ujęciu życie człowieka przestaje być społecznym wytworem, a staje się „doskonałym artefaktem społecznym", spójnym i stałym systemem powiązań (Bourdieu, 1986, ss. 69-72). Biograf produkuje „ja” usymbolicznione, co niekiedy, na przykład w przypadku takich postaci, jak Wanda Wasilewska, jest tym łatwiejsze, że oznacza właśnie uruchomienie "gotowego" potencjału symbolicznego.

\section{„Żotnierz w walce o wielkie sprawy” (Syzdek, 1975, s. 74)}

Kiedy w latach pięćdziesiątych XX wieku powstawały pierwsze radzieckie biografie Wandy Wasilewskiej, ich głównym celem było ukazanie jej jako konsekwentnej komunistki (Usievich, 1953; Vengerov, 1955). Komunistyczna tożsamość uchodzić miała nie za coś nowego, „nabytego”, ale stałego, trwałego, niemal wrodzonego. Opowieść biograficzna konstruowana według schematu narracji hagiograficznej pokazywała więc, jak bez mała od najmłodszych lat bliskie były Wasilewskiej idee komunistyczne, głęboka troska o lud, jak konsekwentnie budowała swoją pozycję w ruchu komunistycznym, jak wreszcie - w uznaniu zasług - otrzymywała liczne nagrody i wyróżnienia za swoją działalność.

Był oczywiście z Wasilewską problem zasadniczy: oto urodziła się i wychowała nie w rodzinie komunistów, ale PPS-owców - ministra spraw zagranicznych w pierwszym rządzie II Rzeczypospolitej, Leona, oraz Wandy z Zieleniewskich; rodzinie aktywnie zaangażowanej w działalność Legionów, a w dodatku krytycznej tak wobec Rosji carskiej, jak i Związku Radzieckiego. Tę kartę z jej życiorysu „korygowano” o tyle, o ile to było możliwe - często w oparciu o późniejszą twórczość literacką i wspomnienia. W myśl socrealistycznej doktryny o zgodności literatury i biografii twórcy przedwojenne powieści Wasilewskiej Oblicze dnia (1934), Ojczyzna (1935) i Ziemia w jarzmie (1938), a także wiersze, reportaże, opowiadania oraz książki dla młodzieży, w których kreśliła mroczny obraz stosunków społecznych w kapitalizmie, postrzegano jako dowód jej głębokiej, niemal „zapisanej na ciele", znajomości warunków życia robotników i chłopów². Podkreślano także

2 Chodzi o fragment biografii pióra Eleny Usievich (pol. Heleny Usijewicz), w którym autorka szuka potwierdzenia tego, że Wasilewska znała warunki życia chłopów, w jej doświadczeniach z dzieciństwa spędzonego w czasie pierwszej wojny światowej we wsi Żarnówka pod Krakowem. Jak pisze Usijewicz, głód, ciężka praca dzieci - wszystkie 
rewolucyjny charakter tej twórczości: Jerzy Putrament sytuował jej pierwsze powieści w nurcie literatury społecznie zaangażowanej, mającej swój początek w pisarstwie Stefana Żeromskiego, i chwalił ją za „rewolucyjną odwagę”, której „Żeromskiemu zabrakło”; ona zaś ją miała, gdyż „zrozumiała historyczne znaczenie Rewolucji Październikowej” (Putrament, 1953, ss. 10-11).

Wczesne biografie akcentowały „jak najwcześniejsze” sympatie komunistyczne Wasilewskiej, wyraźnie usiłując poradzić sobie z faktem, że przed wojną należała nie do Komunistycznej Partii Polski, lecz do Polskiej Partii Socjalistycznej. Pisano więc o kontaktach Wasilewskiej z komunistami - ideowym zbliżaniu się towarzyszy, które zaowocowało organizacją strajku murarzy w Krakowie w 1933 roku, wspólnym tworzeniem radykalnie lewicowych gazet („Oblicze Dnia”, „Dziennik Popularny”), redagowaniem „Płomyka” i „Płomyczka" - czasopism dziecięcych wydawanych przez Związek Nauczycielstwa Polskiego (tzw. numer radziecki „Płomyka” z marca 1936 roku stał się przedmiotem politycznej awantury, która znalazła swój finał na sali sądowej), udziałem w Kongresie Pracowników Kultury we Lwowie w 1936 roku, zorganizowaniem strajku okupacyjnego pracowników Zarządu Głównego ZNP w 1937 roku.

Z opowieści o przedwojennych losach Wasilewskiej wyłaniała się postać młodej „tytanki”: kobiety wszechstronnej, zaangażowanej na wielu „frontach”, walczącej z niesprawiedliwością, wyzyskiem, nędzą mas i chwytającej się każdego sposobu, by zrealizować zakładane cele. Opowieść o młodzieńczych latach „przemawiała” językiem jej bohaterów literackich, jej wiecowych płomiennych odezw, jej plastycznej, obrazowej publicystyki. Wasilewska była w niej żywiołowa, energiczna jak jej pisarski styl, lubiła działać, znajdować się w centrum wydarzeń, ale też cechowała ją wrażliwość na krzywdę bezbronnych, pochylała się nad cierpieniem słabych. Była niezłomna, nonkonformistyczna: garnęła się do komunizmu, mimo iż wzrastała w środowisku niechętnym tej idei, a także mimo nieustannego zagrożenia aresztowaniem za działalność na granicy legalności (Usievich, 1953, s. 58).

O ile okres przedwojenny ukazano w radzieckich biografiach Wasilewskiej jako czas swoistego dojrzewania do czekających ją wyzwań, o tyle wojnę przedstawiono jako moment kulminacyjny jej rewolucyjnej aktywności. Sprzed czerwca 1941 roku przypominano przede wszystkim jej poparcie dla zjednoczenia ziem ukraińskich i białoruskich, oderwanych od „pańskiej Polski” we wrześniu 1939 roku. Wasilewską - kandydującą w marcu 1940 roku do Rady Najwyższej ZSRR - wykreowano na reprezentantkę zamieszkującej Lwów ludności ukraińskiej, polskiej i żydowskiej, żarliwą internacjonalistkę, bojowniczkę o cele, które stawiali przed sobą radzieccy komuniści. Helena Usijewicz pisała, iż „od pierwszego dnia Wasilewska czuła się w socjalistycznym państwie u siebie, jak na ojczystej ziemi. Niczym wojownik stanęła w szeregach walczących o socjalizm i z zapałem zabrała się do pracy” (Usievich, 1953, s. 60). Wybór Związku Radzieckiego - „ojczyzny

elementy, które znalazły się później na kartach Ojczyzny oraz Ziemi w jarzmie, znała Wasilewska z własnego doświadczenia (Usievich, 1953, s. 6). 
światowego proletariatu” - jawił się jako „naturalna” konsekwencja wcześniejszych wyborów pisarki, ale też szansa na ocalenie po inwazji hitlerowskiej na Polskę.

Bardzo ważnym punktem radzieckich biografii Wasilewskiej stał się jej udział w wojnie niemiecko-radzieckiej, określanej w ZSRR mianem „wojny ojczyźnianej”: przywdzianie munduru pułkownika Armii Czerwonej, obecność na froncie stalingradzkim, zaangażowanie w wielką akcję propagandową mającą na celu budzenie ducha narodów Związku Radzieckiego i umacnianie ich woli walki z hitlerowskim najeźdźcą. Po raz kolejny doceniono umiejętności oratorskie i pisarskie Wasilewskiej: jej zdolność budowania atmosfery grozy i wojennego terroru, odmalowywania okrucieństwa najeźdźcy i odwagi radzieckiego ludu. Za szczególnie cenne dzieło pisarki biografowie uznali wojenną powieść Tęcza (1942), napisaną na specjalne zamówienie Stalina historię radzieckiej wsi bestialsko gnębionej przez wroga i dzielnie bronionej przez mieszkańców przy wydatnym wsparciu żołnierzy Armii Czerwonej. Leonid Vengerov (pol. Wiengierow) zwracał wprawdzie uwagę, że krytycy zarzucali Wasilewskiej naturalizm niektórych scen powieści, wpływający na obniżenie walorów artystycznych utworu, jednak sam oceniał, że dzieło to „oddawało w sposób prawidłowy postawę ludzi radzieckich w czasie wojny” (Vengerov, 1955, s. 66).

Obok aktywności pisarskiej i oratorskiej biografowie radzieccy podkreślali także polityczne zaangażowanie Wasilewskiej w czasie wojny, szczególnie zaś zorganizowanie Związku Patriotów Polskich oraz Pierwszej Dywizji Piechoty im. Tadeusza Kościuszki - polski wkład w budowę koalicji antyfaszystowskiej. Za symboliczne zwieńczenie patriotycznej i internacjonalistycznej postawy pisarki poczytywali jej decyzję o pozostaniu w Kijowie: po zakończeniu działań zbrojnych Wasilewska wielokrotnie reprezentowała Ukrainę w Radzie Najwyższej ZSRR, z ramienia Związku Radzieckiego angażowała się w światowy ruch pokoju, była także propagatorką idei komunistycznych podczas swych licznych podróży, m.in. do Włoch, Niemiec, Francji, Indii, Birmy, Chin. W uznaniu zasług pisarskich i politycznych kilkakrotnie odbierała najwyższe radzieckie odznaczenia państwowe - Order Lenina i listy gratulacyjne od Stalina.

Radzieckie biografie Wasilewskiej utrzymane były w tonie opowieści heroicznych: przedstawiały narodziny „nowego człowieka”, człowieka-ikonę, wzór rewolucjonistki, internacjonalistki, patriotki, żarliwej mówczyni, wielkiej pisarki (Brzóstowicz-Klajn, 2004, ss. 147-152). Usijewicz pisała z przekonaniem, że „walka z kapitalizmem była jej namiętnością, sensem całego jej życia. Ta walka dyktowała jej zachowanie i ona podyktowała pisarce wszystkie jej książki, pełne szlachetnego patriotyzmu, miłości do swojego narodu, internacjonalistycznego szacunku i współczucia dla wszystkich ludzi pracy na całym świecie” (Usievich, 1953, s. 10). Wiengierow kreślił z kolei portret Wasilewskiej jako „pionierki” literatury socrealistycznej w Polsce Ludowej, a zarazem „jednej z najwybitniejszych pisarek sowieckich [...]. Wielki jest jej wkład w sowiecką kulturę, w zaszczepienie komunistycznych cech w człowieku sowieckim i we wzmocnienie internacjonalnych uczuć i braterstwa z pracującym ludem polskim" (cyt. za: Pickhan, 2008, ss. 92-93). 
W toku tych opowieści Wasilewska przeistaczała się w „żywą alegorię” rewolucji komunistycznej, ucieleśnienie jej ideałów i cech: walki, poczucia misji, aktywności, odwagi, zaangażowania ${ }^{3}$. Nic dziwnego, że przypominała raczej superwoman niż żywego człowieka. W różnych momentach powracał obraz Wasilewskiej palącej papierosa za papierosem, pijącej hektolitry kawy, z podkrążonymi ze zmęczenia oczami, a jednak ciągle czymś zajętej, ciągle w ruchu. Maria Pryhara, tłumaczka książek Wasilewskiej na język ukraiński, wspominała już po śmierci pisarki: „Potrafiła harmonijnie połączyć talent pisarza i ludowego trybuna z gorącą, szczerą miłością do natury, do wszystkiego, co żyje. Równie wspaniale pisała książki, jak łapała ryby, prowadziła dom i pielęgnowała ogród" (Pryhara, 1982, s. 190).

Niemiecka historyczka Gertrud Pickhan zwraca jednak uwagę, że spójna z pozoru opowieść o Wasilewskiej, którą przed 1989 rokiem wypracowali jej biografowie w oparciu m.in. o wspomnienia samej pisarki i jej przyjaciół oraz rodziny, pełna jest pęknięć, przesunięć w rozkładzie akcentów, przemilczeń albo rozjaśnień wcześniej „niejasnych” kwestii. Pickhan zauważa przede wszystkim, że proces „komunizacji” i „sowietyzacji” pisarki w latach pięćdziesiątych i sześćdziesiątych ${ }^{4}$ zmienit kierunek w latach siedemdziesiątych i osiemdziesiątych XX wieku. W nowszych pracach, szczególnie autorstwa rodzimych badaczek, podjęto „repolonizację” biografii Wasilewskiej. Zaczęła się po odejściu od władzy Władysława Gomułki, z którym łączyły Wasilewską „nienajlepsze” stosunki (by przypomnieć tylko jego zakaz zorganizowania obchodów trzydziestej rocznicy strajku nauczycielskiego z 1937 roku, którym kierowała pisarka), zaś przyspieszenia nabrała w czasach KOR-u i „Solidarności”.

Helena Zatorska skoncentrowała się na przykład na roli Wasilewskiej jako pisarki i pedagożki w latach trzydziestych - postępowej nauczycielki i redaktorki dziecięcych czasopism. Omawiając jej powieści, długo rozwodziła się nad ich polskim kontekstem literackim: nowelistyką Bolesława Prusa i Henryka Sienkiewicza, prozą Elizy Orzeszkowej, Stefana Żeromskiego i Andrzeja Struga; szukała też związków między Ojczyzną Wasilewskiej a Kordianem i chamem Leona Kruczkowskiego oraz utworami Marii Dąbrowskiej. Przestrzegała jednocześnie przed zbytnią funkcjonalizacją wczesnych powieści Wasilewskiej: Oblicze dnia oraz Ojczyzna były utworami literackimi, a nie „broszurą rewolucyjną” czy „polityczną literaturą szkoleniową”, jak chcieliby widzieć pisarstwo Wasilewskiej nie tylko jej przeciwnicy polityczni, ale i „miłośnicy” jej dzieł (Zatorska, 1976, s. 33). Na temat decyzji pisarki o pozostaniu po wojnie w ZSRR, jak też jej tamtejszej aktywności politycznej, milczała: „Nie wydaje się rzeczą słuszną natrętne tropienie osobistych uczuć

30 bohater(k)ach, jak też alegoriach ruchu robotniczego i rewolucji komunistycznej por. Bonnell, 1997; E. Hobsbawm, 1978; Toniak, 2008.

4 Mówiąc o latach sześćdziesiątych, Pickhan ma na myśli przede wszystkim wielogodzinną rozmowę, którą z Wasilewską przeprowadzili historycy z Zakładu Historii Partii KC PZPR. Odbyła się w styczniu 1964 roku w Warszawie i dotyczyła aktywności Wasilewskiej od najwcześniejszych lat do końca wojny. W dyskusji na plan pierwszy wysuwały się związki Wasilewskiej z komunistami i jej stosunek do ZSRR. Pisarka nie zdążyła autoryzować tej rozmowy przed śmiercią w lipcu 1964 roku. Jej zapis opublikowano w dwóch częściach (Wasilewska, 1968, 1982), a niektóre fragmenty dopiero po 1989 roku (Janowski, 1996). 
pisarki i jej przeżyć, związanych z dokonanym wyborem. Co osiągnęła? Jaką cenę za to zapłaciła?" (Zatorska, 1976, s. 93).

Inna polska biografka Wasilewskiej, Eleonora Syzdek, skupiła się z kolei na ukazaniu jej wkładu w organizację polskiego życia kulturalnego we Lwowie w latach 1939-1941, a następnie zaangażowania $\mathrm{w}$ walkę $\mathrm{z}$ faszyzmem, w której zasadniczą rolę miała odegrać jej działalność w Związku Patriotów Polskich (ZPP) i Pierwszej Dywizji Piechoty im. Tadeusza Kościuszki (Syzdek, 1981)5. Syzdek pisała o Wasilewskiej jako o polskiej patriotce, osobie obdarzonej „genialną intuicją” przejawiającą się w „docenieniu momentu patriotyzmu" Polaków skupionych w czasie wojny w Związku Radzieckim i zdeterminowanych do walki z hitlerowskim najeźdźcą. „Intuicja i wiara” miały wyróżniać Wasilewską w środowisku polskich działaczy lewicowych, którzy „bardziej analitycznie i mniej emocjonalnie podchodzili" do kwestii organizacji polskiego wojska w ZSRR. Badaczka kreśliła obraz Wasilewskiej jako osoby „dobrze znającej społeczeństwo polskie, jego tradycje, dążenia niepodległościowe, potrafiącej dzięki tej wiedzy i intuicji wyobrazić sobie efekt podejmowanych wysiłków” (Syzdek, 1981, ss. 150-151). „Emocjonalność” Wasilewskiej, „znajomość Polaków”, współodczuwanie z uciemiężonym narodem miały uzasadniać jej wybór na reprezentantkę polskich interesów w ZSRR, ale też dowodzić jej bezspornej polskości i patriotyzmu: „Dzięki wierze w patriotyzm Polaków, własnym, głębokim uczuciom patriotycznym, potrafiła oddziaływać na kształtowanie postaw i przekonań politycznych mas wychodźstwa polskiego w ZSRR" (Syzdek, 1980, s. 248). Patriotyzm i polskość miały ją sytuować bliżej generała Zygmunta Berlinga, dowódcy Pierwszej Dywizji, niż działaczy komunistycznych, byłych KPP-owców z Alfredem Lampe na czele, o których Syzdek w różnych miejscach wypowiada się dość krytycznie. Mówi o KPP jako o przedwojennej partii „sekciarskiej” (Syzdek, 1980, s. 56) i niezdolnej do przezwyciężenia swej „nieufności” oraz „zamkniętości” także w ZSRR (Syzdek, 1981, ss. 220-221). Niechętnie wspomina również Centralne Biuro Komunistów Polski (CBKP) - ciało powstałe na początku 1944 roku w Moskwie i obsadzone niemal zupełnie przez przedwojennych komunistów, które przejęło kontrolę nad sprawami polskimi w ZSRR, a także „rościło sobie pretensje do arbitralnego wypowiadania się w kwestii działalności PPR w kraju” (Syzdek, 1983, s. 36). Syzdek pokazywała, że utworzenie CBKP zbiegło się w czasie z ograniczeniem politycznej roli Wasilewskiej, dając tym samym do zrozumienia, że przewodnicząca ZPP została wyeliminowana z głównego nurtu wydarzeń na skutek intryg jej niegdysiejszych współpracowników [m.in. pełnomocnikiem CBKP ds. organizacyjnych ZPP została Julia Brystygierowa, która na plenum Zarządu Głównego ZPP w kwietniu 1944 roku skrytykowała Wasilewską za mało sprężyste, a zarazem zbyt skoncentrowane w jednym ręku, kierownictwo (Syzdek, 1981, s. 240)] $]^{6}$.

5 Syzdek zwracała na przykład uwagę na to, że Wasilewska przeznaczyła wysoką nagrodę państwową za powieść Tęcza na budowę samolotu bojowego nazwanego "Warszawa” "dla upamiętnienia bohaterskich obrońców Warszawy, walczących z niemieckim okupantem w 1939 roku” (Syzdek, 1981, s. 118).

6 Wanda Wasilewska została członkinią CBKP, ale nie angażowała się zbyt aktywnie w jego prace. W drugiej połowie lutego 1944 roku poprosiła o trzymiesięczny urlop, a kiedy wróciła, centrum dowodzenia w sprawach polskich znajdowało się już gdzie indziej. W październiku 1944 roku Wasilewska - mimo iż została wiceprzewodniczącą Polskiego Komitetu Wyzwolenia Narodowego (PKWN) - nie wzięła udziału w rozmowach z przedstawicielami rządu londyńskiego oraz z Winstonem Churchillem. Na początku grudnia tego roku zaproponowano jej wyjazd do Paryża 
Niemiecka historyczka Gertrud Pickhan zwraca uwagę, że jedna z prac Syzdek poświęconych Wasilewskiej (Syzdek, 1979) powstała na zamówienie Wojskowego Instytutu Historycznego, który w 1978 roku otrzymał imię pisarki: „Narodowe kodowanie ikony Wasilewskiej, idące w parze ze wskazaniem na (narodowo-)polsko-sowiecką przyjaźń, narzuca się tu w sposób nader oczywisty" (Pickhan, 2008, s. 94). Być może to zaważyto na usytuowaniu Wasilewskiej - zaliczonej do grona „patronów jednostek Ludowego Wojska Polskiego" miejsca poświęcono ostremu konfliktowi między Wasilewską i Berlingiem, o którym mówili i pisali sami zainteresowani: w rozmowie z historykami z Zakładu Historii Partii KC PZPR Wasilewska podkreślała, że z powodu sporu z generałem ograniczyła swoje kontakty z wojskiem do minimum (Wasilewska, 1982, s. 397), zaś Berling w opublikowanych na początku lat dziewięćdziesiątych XX wieku wspomnieniach nie zostawił na przewodniczącej ZPP suchej nitki. Obydwoje oskarżali się o nadmierne ambicje polityczne oraz działanie na szkodę Polski: Wasilewska (podobnie jak Lampe) zarzucała Berlingowi „odchylenie nacjonalistyczne”, zapędy dyktatorskie („tendencje legionowe”) oraz antysemityzm, on zaś krytykował jej „gnuśność”, „trzymanie z komunistyczną sektą” i pragnienie uczynienia z Polski siedemnastej Republiki (do czego jeszcze wrócę) (por. Zwoliński, 2003, ss. 41, 63-83). Próba „odzyskania” Wasilewskiej dla Polski podjęta przez jej biografkę wiodła jednak przez wyciszenie tego sporu, a w zamian wyostrzenie innego - właśnie z komunistami ${ }^{8}$ - ale też przez przyjęcie języka Berlinga w ocenie działaczy byłej KPP („sekta”). Można również zaryzykować stwierdzenie, że Syzdek, pragnąc wtopić swoją bohaterkę w polski naród, zespolić ją z jego ciałem, działała niekiedy wbrew niej samej, jak wtedy gdy przemilczała wspomniany przez Wasilewską fakt nazwania polskiej organizacji w ZSRR mianem „patriotów” przez nikogo innego jak Stalina: „Sam Stalin zaproponował nazwę Związek Patriotów Polskich. W pierwszej chwili bardzo mi się to nie spodobało i mówiłam, że nazwa «patriota» jest dosyć skompromitowana w Polsce. On

W charakterze reprezentantki PKWN, ale nie przyjęła tej funkcji. Wtedy też prawdopodobnie podjęła decyzję, że nie wróci do Polski. Syzdek pisze, że jedną z przyczyn jej decyzji mogła być „nielojalność niektórych działaczy lewicy polskiej w ZSRR, którzy [...] rozstrzygali pewne sprawy bez jej udziału. Ponieważ należała ona do ludzi ambitnych i wrażliwych, przyzwyczajonych do jawności decyzji, do klimatu wzajemnego zaufania, który był dla niej czynnikiem niezbędnym dla angażowania się w działalność społeczną, w powstałych układach personalnych mogła nie widzieć dla siebie miejsca” (Syzdek, 1981, s. 278). Podkreślając różnicę między „wrażliwością” Wasilewskiej i jej „przyzwyczajeniem do jawności decyzji” a intryganctwem, skłonnością do zakulisowych działań „sekciarzy” z byłego KPP, Syzdek kierowała sympatię czytelnika w stronę przewodniczącej ZPP. Zwracała uwagę, że zasługi Wasilewskiej - mimo odsunięcia jej na boczny tor - nie zostały w Polsce zapomniane: za swą aktywność otrzymała Krzyż Grunwaldu I klasy, Order Odrodzenia Polski II klasy, Sztandar Pracy I klasy oraz wiele medali wojskowych. Według Syzdek sama Wasilewska także nie zapomniała o ojczyźnie. Nie tylko często ją odwiedzała, ale też troszczyła się o jej wizerunek w Związku Radzieckim, m.in. w 1950 roku napisała w Kijowie scenariusz do filmu dokumentalnego Polska, w którym „znalazła odbicie gruntowna znajomość demokratycznych i rewolucyjnych tradycji Polski oraz dokonanych w niej przemian po wojnie” (Syzdek, 1981, s. 288).

7 Książeczka Syzdek z 1979 roku ukazała się w serii „Patroni jednostek Ludowego Wojska Polskiego”.

8 W rozmowie z historykami z Zakładu Historii Partii Wasilewska wspominała, że jej spór z Lampem dotyczył kwestii organizacji oddziałów wojska polskiego w ZSRR. Lampe miał być zwolennikiem polskich jednostek wojskowych w ramach Armii Czerwonej, Wasilewska zaś - prawdopodobnie działając w porozumieniu z Rosjanami - forsowała koncepcję osobnej polskiej dywizji. Zwracała uwagę, że konfliktogenna mogła być także jej funkcja reprezentantki polskich spraw w ZSRR: „Wszystkie zasadnicze sprawy szły przeze mnie. W pewnym momencie nawet Lampe postawił rzecz w ten sposób, że chciałby ze Stalinem omówić pewne sprawy. A że do tego nie doszło i w tamtej konfiguracji dojść nie mogło, to też było powodem zadrażnień, jakkolwiek w danym wypadku ja absolutnie żadnej winy nie ponosiłam” (Wasilewska, 1982, s. 427). Podkreślała wszakże, że tuż przed śmiercią Lampego doszło między nimi do spotkania i wyjaśnienia wszystkich nieporozumień: „W każdym razie ten wyjaśniający wieczór skończył się tym, żeśmy się objęli, pocałowali i oboje z wielkim wzruszeniem powiedzieli, jacy jesteśmy szczęśliwi, że to wszystko się skończyło" (Wasilewska, 1982, s. 399). 
mi na to powiedział, że każdemu słowu można nadać nową treść i od was zależy, jaką treść temu nadacie” (Wasilewska, 1982, s. 383). W pracach Syzdek ten „szczegót” nie pojawia się, a w zamian możemy przeczytać o - cytowanych już - „głębokich uczuciach patriotycznych" Wasilewskiej.

Na początku lat osiemdziesiątych XX wieku pod redakcją Eleonory Syzdek ukazał się zbiór wspomnień o Wandzie Wasilewskiej. Złożyły się nań relacje jej przyjaciół i współpracowników, omawiających głównie przedwojenną i wojenną aktywność pisarki: po pierwsze - społecznikowską, socjalistyczną, po drugie - patriotyczną, narodową. Nakreślony w tych wspomnieniach portret Wasilewskiej przed wojną - nauczycielki, działaczki społecznej - wyraźnie uruchamiał skojarzenia z „Siłaczką” Żeromskiego: kobietą energiczną, wrażliwą na krzywdę, gotową nieść pomoc potrzebującym. Z kolei jej role wojenne - płomiennej mówczyni zagrzewającej do walki z niemieckim okupantem, jak również organizatorki-matki polskiego wojska - uparcie odsyłały do polskiego romantycznego imaginarium, w którym znalazło się miejsce dla takich kobiecych patriotycznych figur, jak „Wanda, co nie chciała Niemca”, „pułkownik Emilia Plater”, heroiczna „Matka Polka”, zwycięska „Polonia” (por. Janion, 2006, ss. 259-299). Kolejne „wcielenia” Wasilewskiej rejestrował ukraiński poeta Jurij Smołycz:

„Wanda miała na sobie wojskowy mundur: buty z cholewami i bryczesy, bluzę z dystynkcjami oficerskimi i czapkę, jaką nosiła piechota. Tak pojawiła się na trybunie - podobna do smukłego młodzieńca [...]. Wanda prawie wcale nie umiała jeszcze ani po ukraińsku, ani po rosyjsku. [...] W zasadzie przemawiała po polsku, a jednak wszystko, co mówiła, było zrozumiałe i wzruszające. Wystąpienie składało się tylko z dwóch części: Wasilewska mówiła o zburzonej Warszawie i o zagrożeniu, jakie niesie ludzkości faszyzm. I wtedy właśnie ujrzałem w jej oczach żar [...], więcej - płomień. Była w nim miłość do ojczyzny i nienawiść do jej wrogów [...], gorący płomień trybuna ludowego.

[...] Na trybunę weszła Wanda. [...] było w niej coś niesłychanie romantycznego, powiew odległych epok, wspomnienie średniowiecznych rycerzy. [...] - kobieta w długiej szacie z podniesionym kapturem. Kobieta przyjmuje twoją przysięgę: będziesz wierny Ojczyźnie i niezłomny w boju. Ta kobieta to twoja matka, twoja siostra, twoja żona, twoja córka czy narzeczona... Z jej ust padają słowa przysięgi. Jej ślubujesz wierność: matce, siostrze, żonie, córce, dziewczynie - za naszą wolność i Waszą!” (Smołycz, 1982, ss. 194-195, 200-201).

Uważna lektura wspomnień zebranych przez Syzdek pozwala dostrzec, że powojennej działalności Wasilewskiej poświęcono najmniej miejsca, chociaż okres ten trwał dwadzieścia lat i obfitował zarówno w nowe funkcje polityczne, jak i dokonania literackie. Można wręcz odnieść wrażenie, że Wasilewska zakończyła swoją aktywność wraz z końcem wojny: po okresie wielkich zmagań nadszedł czas „kobiety domowej”, która niańczy wnuka, gotuje i pieli ogródek, a jeśli przyjeżdża do Polski, to tylko w sprawach prywatnych: „Widziałam w niej pisarkę, wielką działaczkę polityczną, a tu się okazało, że Wanda bardzo lubi dom, gospodarstwo domowe, pracę w kuchni. Często mówiła, że [...] zawsze marzyła o normalnym życiu i o tym, by mieć dom i zajmować się nim, a musi robić co innego" - pisała Maria Sokorska (Sokorska, 1982, s. 142). Ten schemat opowieści wyraźnie 
unieruchamiał Wasilewską w „kobiecej roli”, co odpowiadało tradycyjnemu postrzeganiu miejsca kobiet w (polskiej) historii: po wojennym „odwróceniu ról płciowych” „znów mogły być kobietami” (por. Kusiak, 2006). Droga do wtopienia Wasilewskiej w polskość najwyraźniej miała wieść przez jej kobiecość.

\section{„Bogini zta” (cyt. za: Słowiński, 2010)}

Po 1989 roku jasną legendę Wandy Wasilewskiej wyparła mroczna opowieść, której dominantą stała się kategoria „zdrady narodowej”. W ramach tej narracji przewodnicząca ZPP funkcjonuje jako „renegatka”, która przyjęła radzieckie obywatelstwo, a mieniąc się reprezentantką narodu polskiego, wraz ze Stalinem „pokroiła” Polskę tak, by znaczna część „ziem wschodnich” przypadła po drugiej wojnie światowej ZSRR. Ten obraz Wasilewskiej pochylającej się ze Stalinem nad mapą Polski, do złudzenia przypominający inny: carycy Katarzyny układającej się w sprawie polskiego terytorium z władcami Prus i Austrii, jest chyba najbardziej plastycznym wizerunkiem przewodniczącej ZPP, najsilniej utrwalonym na kartach najnowszej polskiej historii. Oto kobieta, Polka, układa się z wrogiem, dyktatorem, targując się o najmniejszą piędź ziemi ojczystej nie na korzyść Polski, lecz przeciwnie - na jej zgubę. Scena ta nie ma w sobie nic z popularnej narodowej ikonografii: Wasilewska nie jest ani bohaterską obrończynią ojczyzny, ani braną gwałtem bezbronną niewiastą; nie jest ani heroiczna, ani niewinna. Jest pragmatyczna, urzędowa, negocjuje, a wreszcie dobija targu; jest „handlarką”: handluje Polską, „żywym ciałem ojczyzny”, a być może i swoim, jeśli przywołać powtarzane do dziś plotki o jej romansie ze Stalinem (por. Kuncewicz, 1995, s. 397).

Scena z mapą jest symboliczna także z innego względu: oto w 1921 roku ojciec Wasilewskiej był w składzie polskiej delegacji, która w Rydze negocjowała warunki traktatu pokojowego z ZSRR i domagała się przywrócenia granicy sprzed rozbiorów. Tymczasem - jak pisze Joanna Szczęsna - prawie ćwierć wieku później jego córka zrobiła gest odwrotny i „zrzekła się” tego, co jej ojciec „wywalczył”10. Podobnej zbieżności czy raczej rozbieżności w zachowaniu ojca i córki upatruje w ich działalności agitacyjnej: o ile „na polecenie Piłsudskiego w sierpniu 1914 roku Leon pisze odezwę do Legionów («Polska przestała być niewolnicą i chce stanowić o swym losie sama, rzucając na szalę wypadków własną siłę orężną»)", o tyle „niespełna trzydzieści lat później [jego] córka Wanda na rozkaz Stalina napisze rotę przysięgi dla tworzącego się w Sielcach polskiego wojska i włoży do niej zdanie o wierności wobec ZSRR. Czy w naiwności swej uważa, że powtarza drogę ojca, bo jak on zagrzewa polskich żołnierzy do walki? A może przeciwnie, buntuje

9 Eleonora Syzdek podaje, że po raz pierwszy określenia „renegatka” użył Kazimierz Pużak w rozmowie z Jerzym Ruszowskim jeszcze w okupowanej przez hitlerowców Warszawie. Z kolei mianem „zdrajców” określił Wasilewską i Berlinga generał Władysław Sikorski w depeszy do dowódcy Armii Krajowej generała Stefana Grota-Roweckiego z 28 listopada 1942 roku (Syzdek, 1981, s. 61).

10 Szczęsna przytacza relację Ksawerego Pruszyńskiego, który - jako dyplomata - spotkał się z Wasilewską latem 1942 roku i poznał jej koncepcję „Polski Bolesława Krzywoustego”. Dyskredytując „realny wpływ” Wasilewskiej na kwestię powojennych granic, Szczęsna podkreśla jednak, że „ten obrazek - Stalin i Wasilewska nad mapą Polski okrawają jej wschodnie granice - wraca uporczywie w powojennych plotkach, wdziera się do pamiętników, pogarsza jej już i tak fatalną reputację renegatki” (Szczęsna, 2001). 
się przeciwko niemu, jak to czyniła i za jego życia? Tak czy inaczej w Historii Polski Poboga-Malinowskiego dorobiła się Wasilewska miana «wyrodnej córki Leona»" (Szczęsna, 2001). W tekście Szczęsnej postać ojca urasta do rozmiarów symbolu: to wzór patrioty, intelektualisty, polityka, któremu córka nigdy nie dorównała, a wręcz stała się jego przeciwieństwem, o czym pisali cytowani przez autorkę Adam Ciołkosz, Aleksander Wat, Julian Stryjkowski. Tym samym „zdrada” Wasilewskiej okazuje się podwójna - narodowa i rodzinna: „wyrzekając się” Polski, Wanda „wyrzekła się” także ojca i ojcowskich ideałów, „zhańbiła” się jako Polka i jako „córka Leona”.

Wspomniany obraz - Wasilewska ze Stalinem pochyla się nad mapą Polski - „uwiecznia” ją jako postać jednoznaczną: to „zdrajczyni”, „renegatka”, „akuszerka PRL-u - pokracznego tworu, którego ojcem był Stalin” (Niemiec, 2011), „bogini zła - okrutna, żądna władzy, występna” (Słowiński, 2010), „polski Quisling w spódnicy”, „kapłanka ponurej politycznej ceremonii” (Trznadel, 1998, ss. 36, 388). Ten jeden obraz „zamyka” całe życie Wasilewskiej: wszystkie jej wcześniejsze działania, decyzje, wybory stają się „czytelne”, przejrzyste, prowadzą bowiem do tej właśnie chwili, tak jak cała późniejsza działalność przewodniczącej ZPP jawi się jako chwili tej konsekwencja. Ma ona wyjaśniać i wydanie „radzieckiego numeru” „Płomyka”, i przyjmowanie honorariów od ambasady ZSRR w Polsce za przekłady jej książek na język rosyjski, i przyjęcie radzieckiego obywatelstwa w pierwszym okresie wojny, i wreszcie pozostanie poza granicami Polski po 1945 roku. Wasilewska-komunistka objawia się jako sowiecka agentka, która „zdekonspirowała się” po 1939 roku, a później zamieszkała w ZSRR, by służyć swojej „prawdziwej ojczyźnie”. Ta Wanda nie tylko nie umarła (nie wybrała śmierci), ale dobrowolnie „poślubiła wroga” i wniosła mu w posagu pokaźne wiano: nie tylko „ziemie wschodnie”, ale i całą Polskę jako radzieckiego „satelitę". Po latach niezwykle ostro pisała o Wasilewskiej Maria Dąbrowska:

„[10.V.1956] Wanda Wasilewska wyparła się ojczyzny, wtedy kiedy Polska leżała zdruzgotana i pokonana. - Wyparła się aktywnie, nie już krytykując, ale spotwarzając Polskę. W publicznych przemówieniach we Lwowie pozwalała sobie mówić, że żyła w Polsce jak zaszczute zwierzę i że teraz dopiero odnalazła ojczyznę. To nikczemne kłamstwo. W Polsce nigdy włos jej z głowy nie spadł. Brała grubą forsę za książki i za „Płomyka”. [...] Zdradziła tak samo lud - gdy na gruzach ojczyzny panoszyła się w pięknej wilii - a miljony polskich ludzi gnane były na Sybir. - Trudno o czystszą formę zdrajcy i renegata. Przypuszczam zresztą, że to typ kryminalnej awanturnicy i nie zdziwiłoby mnie to, gdybym dowiedziała się, że brała jakiś udział w zamordowaniu swego pierwszego (czy nie wiem którego z rzędu) męża" (Dąbrowska, 2009, ss. 41-42).

Obraz, jaki nakreśliła Dąbrowska, nie tylko podtrzymywał wizerunek Wasilewskiej jako „zdrajczyni” i „renegatki”, ale szedł dalej, sugerując jej udział w zbrodni - zabójstwie drugiego męża, murarza Mariana Bogatki, który został zastrzelony w niewyjaśnionych okolicznościach wiosną 1940 roku we Lwowie. Sugestie odnośnie zbrodniczej (ludobójczej niemal) działalności Wasilewskiej znajdziemy także w niepublikowanym dzienniku pisarki Józefy Radzymińskiej: 
„[12.02.1982] Wanda Wasilewska przybyła z Moskwy do okupowanej Warszawy na zaproszenie Niemców w 1940 roku i była obwożona w asyście gestapowców - ówczesnych przyjaciół Stalina. Tak zbrodniarze podawali sobie ręce na naszą zgubę. Nie wiadomo też, czy supozycja, że to Wasilewska zasugerowała Stalinowi wymordowanie «sanacyjnych oficerów» w Katyniu, nie jest prawdziwa!" (Radzymińska, b.d., s. 226) ${ }^{11}$.

W dzienniku Dąbrowskiej i Radzymińskiej „zdrada narodowa” staje się najcięższym przewinieniem za sprawą skojarzenia z „morderstwem” czy wręcz „ludobójstwem”. Autorki nie zastanawiają się, czy ich podejrzenia odnośnie do jakiegokolwiek związku Wasilewskiej z zabójstwem męża ${ }^{12}$, a tym bardziej z podżeganiem do mordów w Katyniu ${ }^{13}$ są uzasadnione. Żywią raczej przeświadczenie, że po osobie, która „zdradziła ojczyznę”, można się spodziewać wszystkiego ${ }^{14}$. To „wytwarzanie” komunistki jako „zbrodniarki” odbywa się przy założeniu, że „naród” czy „ojczyzna” to wartości równoznaczne z życiem, a więc najwyższe.

„Zbrodnia”/„zdrada” narodu „ustawia” całą biografię Wasilewskiej i waży na ocenie jej przedwojennej, wojennej i powojennej działalności. Adam Ciołkosz, jej znajomy jeszcze z krakowskiego PPS-u, pisze, że we wrześniu 1939 roku w Kowlu „wymieniła swoją narodowość polską na narodowość sowiecką" (Ciołkosz, 1977, s. 27), z czym wiązać się miało późniejsze „majstrowanie” przy życiorysie, którego podjęła się sama lub jej biografowie.

11 Dziękuję dr Katarzynie Stańczak-Wiślicz z Instytutu Badań Literackich PAN za zwrócenie uwagi na ten cytat.

12 Zabójstwo Bogatki nigdy nie zostało wyjaśnione. Nie wiadomo, czy celem był Bogatko czy Wasilewska; nie wiadomo, dlaczego wykonano wyrok. Oficjalne wyjaśnienia głosiły, że zginął z ręki „kontrrewolucjonistów” - w jednej wersji „ukraińskich”, w innej „polskich”. Eleonora Syzdek nie wyklucza, że „był to zamach na życie samej Wasilewskiej”, której „wybór do Rady Najwyższej wpłynąt na umocnienie jej autorytetu w całym ZSRR” (Syzdek, 1981, s. 78). Aleksander Wat w Moim wieku sugeruje natomiast, że Bogatko zginął, bo zbyt otwarcie krytykował poczynania władz radzieckich we Lwowie. Nie wyklucza jednak, że jego śmierć była swoistą „nauczką” dla Wasilewskiej, by nie wtrącała się za bardzo w sprawy radzieckie, np. by nie interesowała się zanadto losem różnych zatrzymanych przez NKWD osób (w tym samego Wata): [...] prawdziwa, świetna szkoła stalinowska, żeby nie miała złudzeń. Point de rêveries. Od razu. Jednorazowy szok. Zen. Po łbie i cała zestrukturalizowana świadomość. Następuje pieriekowka duszy" (Wat, 2011, s. 318). 0 tym, że zabójstwa dokonało NKWD, pisze w swoich pamiętnikach Nikita Chruszczow. Zastrzega, że była to pomyłka i że osobiście zlecił Aleksandrowi Kornijczukowi, by w jego imieniu przeprosił Wasilewską: „Od razu zrodziło się pytanie: jak ta sprawa odbije się na stosunku Wasilewskiej do nas? Czy nie pomyśli, że usunęliśmy jej męża z jakichś politycznych powodów? Różne rzeczy mogą przyjść człowiekowi do głowy w następstwie takiej tragedii”. Podobno czekiści wzięli Bogatkę za kogoś innego, a sądząc, że jest uzbrojony, zaczęli strzelać. Chruszczow twierdzi, że Wasilewska „uwierzyła, że nie było w tym przypadku premedytacji, i aktywnie pracowała dalej" (Chruszczow, 2000, s. 140).

13 Z sugestią, że Wasilewska mogła podsunąć Stalinowi myśl o wymordowaniu polskich oficerów w Katyniu, zetknęŁam się dopiero za sprawą wzmianki w dzienniku Radzymińskiej. W sprawie mordów w Katyniu przewodnicząca ZPP prezentowała wprawdzie oficjalne stanowisko władz radzieckich (np. w artykule Mord w Katyniu z 1 lutego 1944 roku), ale nie jest to równoznaczne z tym, że „sugerowała wymordowanie”. Fragment wspomnień Wasilewskiej dotyczący jej wiedzy o Katyniu ukazał się drukiem dopiero po 1989 roku. 0 sprawie nie mówiła jasno: wspominata o oficjalnych działaniach władz radzieckich w odpowiedzi na informację o odkryciu grobów, m.in. o powołaniu komisji i o tym, że stronę polską reprezentował w niej Jerzy Borejsza, ale też opisywała ogólny popłoch, jaki ta informacja wywołała wśród Polonii, ni to go rozumiejąc, ni to bagatelizując: „Co było w Katyniu i jak? - w danym momencie ich [szerokie masy - przyp. A.M.] to mniej interesowało niż to, czy jutro nie zostaną aresztowani i jak potoczą się ich dalsze losy, które w pewnej wojennej mierze były ustabilizowane. Nagle wszystko się wali i rozlatuje, co ci bolszewicy z nimi zrobią, jeszcze nie wiadomo. W szerokich masach emigracyjnych sprawa Katynia utonęła właściwie wobec tych codziennych problemów, które przed ludźmi stanęły bardzo ostro i nieprzyjemnie od razu i z miejsca" (Janowski, 1996, ss. 136-137).

14 Jeśli chodzi o kwestię kontaktów Wasilewskiej z gestapo, to wydaje się, że Radzymińska pisze o wydarzeniu, które nie miało miejsca, myląc je widocznie ze sprawą przetransportowania do Lwowa właśnie przez gestapo córki Wasilewskiej, Ewy, siostry Zofii Aldony z córką oraz Marii Zarębińskiej (drugiej żony Władysława Broniewskiego) z córką Majką. Syzdek podaje, że stało się to na polecenie Stalina tuż po jego pierwszej rozmowie z Wasilewską. Sprawa została załatwiona drogą dyplomatyczną późną jesienią 1939 roku, kiedy ZSRR i III Rzesza były jeszcze w dobrych stosunkach (Syzdek, 1981, s. 68). We wspomnieniach Mariana Czuchnowskiego oraz Adama Ciołkosza to wydarzenie zostało zrelacjonowane w sposób mocno krytyczny: Czuchnowski pisze, że Wasilewska wydostała córkę z Warszawy, korzystając z przywilejów, a Ciołkosz podkreśla, że matka pisarki „nie skorzystała z uprzejmości gestapo i została w Warszawie" (Czuchnowski, 1945; Ciołkosz, 1977). 
Ciołkosz stawia sobie za cel demitologizację postaci Wasilewskiej. Zaczyna od sprecyzowania, że do czasu przeniesienia się do Warszawy, a więc do 1934 roku, „nie była ona niczym związana z partią komunistyczną. Była radykalna w tym samym sensie, w jakim cała PPS była podówczas radykalna" (Ciołkosz, 1977, s. 16). Dyskredytuje oryginalność jej poglądów na podziały klasowe w Polsce międzywojennej, pisząc, że wizja „dwóch ojczyzn" Wasilewskiej: pańskiej i chłopskiej, którą rozwijała w powieści Ojczyzna, nie była niczym nowym i „odpowiadała polskim socjalistom niepodległościowym całkowicie” (Ciołkosz, 1977, s. 42). Według Ciołkosza, do momentu „zerwania z polską ojczyzną” poglądy Wasilewskiej nie odbiegały zbytnio od poglądów większości członków PPS. Dopiero w chwili, gdy zdecydowała się „zastąpić polską ojczyznę, czy też dwie polskie ojczyzny, jedną nową ojczyzną, rosyjsko-sowiecką", ich drogi się rozeszły (Ciołkosz, 1977, s. 43).

Ciołkosz protekcjonalnie wypowiada się o zaangażowaniu Wasilewskiej w komunizm, ironizując, że „nie była tak bezkompromisową przodownicą rewolucji, jak to usiłują ukazać różni historycy w Moskwie i Warszawie" (Ciołkosz, 1977, s. 18). Podkreśla, że była niedouczona, jeśli chodzi o „wiedzę teoretyczną w zakresie socjalizmu”: jako rewolucjonistka miała być „nowym wydaniem Róży Luksemburg”, jednak nie miała intelektu poprzedniczki (Ciołkosz, 1977, s. 47) 15; nadrabiała „egzaltacją, którą jednak trudno było brać na poważnie” (Ciołkosz, 1977, s. 42). Także jej „praktyczna” działalność pozostawiała wiele do życzenia: jej zaangażowanie w krakowski strajk murarzy w 1933 roku było skromne („Nie strajkowała. Była jednak bardzo czynna w akcji pomocy dla strajkujących”), a całe wydarzenie „zakończyło się zwycięstwem pozornym” (Ciołkosz, 1977, s. 12); z kolei nagłaśniany jako wielki sukces strajk nauczycielski z 1937 roku „nie był tak wielką walką [...], za jaką się go dziś przedstawia” (Ciołkosz, 1977, s. 18). W kilku też miejscach wraca Ciołkosz do kwestii rzekomych szykan i prześladowań Wasilewskiej przez policję, zaznaczając, że według jego wiedzy nigdy - jako córka ministra spraw zagranicznych w pierwszym rządzie II Rzeczypospolitej - nie siedziała w więzieniu:

„Do chwili wybuchu drugiej wojny światowej Wasilewska nigdy nie zaznała surowości reżimu, o której sama tyle pisała i o której pisze jej biografka [Helena Usijewicz - przyp. A.M.]. [...] ta polska Pasionaria ani razu (powtarzam: ani razu) nie zaznała piołunowego smaku chleba, ani razu nie oglądała zakratowanej celi od wewnątrz, ani razu nie spadła na nią pałka policjanta. Zawsze jej strzegły jakieś dobre wróżki” (Ciołkosz, 1977, ss. 21, 47).

Dyskredytacji Wasilewskiej jako działaczki komunistycznej we wspomnieniach Ciołkosza towarzyszy równoległe akcentowanie jej „miłości do Rosji i Stalina”, czy też „komunizmu moskiewskiego obrządku”. Kategoria „narodu” jest tu istotna, szczególnie w zestawieniu z inteligenckim pochodzeniem Wasilewskiej, gdyż ma demaskować „prawdziwe” intencje Wasilewskiej: oto w swych wyborach nie kierowała się miłością do polskiego ludu [wszak swojego męża, murarza Bogatkę, „skrzywdziła ciężko, deklasując i przenosząc do środowiska literackiego. Nie stał się literatem, nie miał po temu żadnych danych, za to przestał być murarzem” (Ciołkosz, 1977, s. 58)], ale „ślepą miłością” do Związku

15 Podkreśla to także Czuchnowski, który pisze, że „w życiu nie przeczytała stronicy Marksa, Engelsa, Bebla, Kautzkiego, Lenina, Plechanowa, cóż mówić o Bucharinie czy Trockim” (cyt. za: Trznadel, 1998, s. 411). 
Radzieckiego, który „kochała w całości, bez zastrzeżeń i bez wyjątków” (Ciołkosz, 1977, s. 33). Ze szkiców Ciołkosza płynie więc wniosek, że Wasilewska nie była „prawdziwą” komunistką, w 1939 roku przestała być Polką, za to stała się Sowietką, choć - jak zastanawia się sam autor - „czy taka narodowość istnieje? A czy istniała narodowość austriacko-węgierska, czechosłowacka, jugosłowiańska? Spór na ten temat jest bezcelowy i bezużyteczny. Wanda Wasilewska udowodniła swój patriotyzm sowiecki słowem i czynem" (Ciołkosz, 1977, s. 28).

Uwagi Ciołkosza są dziś chętnie cytowane jako uwagi „obiektywnego świadka”: tego, który znał Wasilewską „prawdziwą”, inną, niż ta uwieczniona na kartach oficjalnych biografii. Fakt, że pisał swoje szkice w Londynie i wypowiadał się jako przywódca PPS-u na emigracji, a zatem polityczny przeciwnik Wasilewskiej, nie tylko nie umniejsza wiarygodności jego głosu, ale wręcz przeciwnie - wzmacnia go. Co ciekawe, nie umniejsza jej także fakt z życiorysu samego Ciołkosza: to, że znał Wasilewską krótko, bo wyłącznie z okresu jej aktywności w Krakowie, a i tu ich drogi zaczęły się w pewnym momencie rozchodzić ${ }^{16}$. Mimo to Ciołkosz pozostaje „wiarygodny” podobnie jak inny znajomy Wasilewskiej, generał Zygmunt Berling, chociaż wiadomo, że wcześnie popadł z nią w konflikt. Jakub Berman w rozmowie z Teresą Torańską wspomina, że chodziło o odmienną wizję porządku w powojennej Polsce, a przy okazji o ambicje obojga: o to, jak będzie wyglądał nowy ustrój i jaką rolę w jego kształtowaniu odegrają ZPP i armia, przy czym sympatia Bermana jest wyraźnie po stronie Wasilewskiej, a nie Berlinga, którego posądza o zapędy dyktatorskie, nacjonalizm i antysemityzm (Torańska, 2012, ss. 37-40). W trzech tomach wspomnień Berling przedstawia jednak całą sprawę inaczej, dowodząc, że od pierwszej chwili poróżniła go z Wasilewską kwestia patriotyzmu. Przypomina, że zrobiła na nim jak najgorsze wrażenie już w momencie poznania, kiedy na jego pytanie o to, „co będzie z tymi kilkunastoma setkami tysięcy naszych emigrantów i deportowanych z Polski, co będzie z naszą sprawą - odpowiedziała, że nie wie, i dodała (przytaczam dosłownie): «Ja jestem obywatelką radziecką i członkiem WKP(b), od spraw polskich odeszłam i nic mnie to nie obchodzi». Nie było to pełnym zaskoczeniem, ale takiej odpowiedzi nie spodziewałem się w najgorszych wyobrażeniach" (Berling, 1991a, s. 33). Ta wypowiedź Wasilewskiej, którą przytacza także żona Berlinga, Maria (Berlingowa, 1990, s. 69), jak również ocena przewodniczącej ZPP przez pułkownika NKWD Wiktora Kondratika: „Kiedy będzie trzeba, Wanda Lwowna zrobi, co jej każą", stają się swoistym leitmotivem pamiętników generała. Berling przypomina je szczególnie przy okazji relacjonowania swojego sporu z Wasilewską o „ziemie wschodnie”. Podkreśla, że kiedy on walczył o pozostawienie przy Polsce Lwowa, Wasilewska była rzeczniczką uczynienia z Polski siedemnastej Republiki Radzieckiej (Berling, 1991b, s. 354).

16 Ciołkosz poznał Wasilewską w 1923 roku, kiedy wstąpiła do Związku Niezależnej Młodzieży Socjalistycznej. 0 tym, że jeszcze w okresie krakowskim ich drogi zaczęły się rozchodzić, mówiła Wasilewska w rozmowie z historykami z Zakładu Historii Partii. Zwracała uwagę, że od przełomu lat dwudziestych i trzydziestych XX wieku w krakowskiej PPS zaczęły się tworzyć różne frakcje, z których jedne (z Ciołkoszem) chciały zachować dotychczasową, reformistyczną linię działania, a inne (z Wasilewską i jej późniejszym mężem, Marianem Bogatką) dążyły do podjęcia bardziej radykalnych kroków, szukając zbliżenia z komunistami (Wasilewska, 1968, ss. 124-131). 
Berling, który sam przeszedł do historii jako autor słynnego listu do Stalina, gdzie "błagał o uratowanie Polski z rąk trockistowskiej szajki międzynarodowego bandytyzmu”, jak nazywał „grupę Wasilewskiej” (m.in. Jakuba Bermana, Hilarego Minca, Julię Brystygierową, Alfreda Lampego) (Berling, 1991b, s. 386), kreuje się w pamiętnikach na jednego z nielicznych obrońców polskości w ZSRR w czasie drugiej wojny światowej, jedynego godnego przeciwnika przewodniczącej ZPP. Ostra krytyka, której poddaje jej osobę, dotyczy przede wszystkim „błędu luksemburgizmu”, jak nazywa jej internacjonalistyczne poglądy, powtarzając obiegowe określenie Wasilewskiej - „renegatka”: „Oto teraz renegatka, kryminalista, półgłówek i nieokrzesany nieuk i cham tworzą parawan, za którym elita wybranego narodu: Berman, Zambrowski, Minc i Szyr, ujmuje w swe ręce ster rządów w państwie" (Berling, 1991b, s. 383) ${ }^{17}$. Wysuwa jednak także pod jej adresem inne zarzuty, głównie natury organizacyjnej. Podkreśla na przykład, że była gnuśna, leniwa i źle kierowała pracami ZPP, przerzucając swoje obowiązki na innych. Nie rozumie też, skąd jej sława doskonałej mówczyni ani tym bardziej polityka.

Dla tej ostatniej opinii znajduje wsparcie w pamiętnikach swojego zastępcy w armii, Włodzimierza Sokorskiego, który pisze, że Wasilewska była „potwornie głupia i politycznie szła na wszystko, w tę czy tamtą stronę" (cyt. za: Trznadel, 1998, s. 423). Podobnie jak w przypadku Ciołkosza i Berlinga, głos Sokorskiego - nawet przy założeniu, że „w swoich wspomnieniach był bliski magla”, jak zauważa Szczęsna (Szczęsna, 2001) - jest dziś chętnie przywoływany. To od niego pochodzi informacja, że Wasilewska „popełniła samobójstwo", nie mogąc po wojnie znieść pustki wokół siebie (cyt. za: Zawiśliński, 1991). Sokorski jest zresztą ciekawym przykładem „świadka”, który w swej ocenie Wasilewskiej wielokrotnie zmieniał zdanie: do 1989 roku pisał o niej raczej ciepło, po przełomie z wyraźną niechęcią.

„Czarna legenda” Wasilewskiej utrzymana jest w konwencji opowieści o zbrodni i karze. Za bezsprzeczną „zbrodnię” zdrady narodowej Wasilewska miała drogo zapłacić jeszcze za życia. Motyw „kary” pojawia się w plotkach o ostatnich dwudziestu latach jej życia. Zdaniem Ciołkosza to, że nie wróciła do Polski i nie zajęła żadnego eksponowanego stanowiska, było konsekwencją jej wyborów dokonanych jeszcze jesienią 1939 roku: „Za wcześnie i zbyt demonstracyjnie wskoczyła w roku 1939 na głęboką sowiecką wodę. Inni dygnitarze PKWN byli albo nieznani, albo mało znani, nie wywoływali zachwytu, ale też i nie budzili nienawiści, natomiast ją otaczała nienawiść i pogarda, powszechna opinia Polaków uważała ją za renegatkę" (Ciołkosz, 1977, s. 56). Jako polityczka nie miała zatem

17 Zdaniem Berlinga nazywanie Wasilewskiej polską patriotką to całkowite nieporozumienie:

„Wola Stalina zawróciła Wasilewską z drogi luksemburgizmu. Bez wahania rzuciła swoich dotychczasowych towarzyszy i jak za dotknięciem czarodziejskiej różdżki odrodził się jej polski patriotyzm. [...] znam ją na tyle, że mam prawo nie wierzyć w żaden jej patriotyzm, ani polski, ani radziecki. Może gdzieś głęboko tliło się w niej coś, co można by najwyżej nazwać przywiązaniem do dawnych przeżyć, ale to ma niewiele wspólnego z Polską i wcale nie jest pewne" (Berling, 1991a, ss. 303, 306).

W patriotyczne intencje Wasilewskiej powątpiewali także inni, na przykład Marian Czuchnowski - przed wojną członek radykalnego ruchu ludowego i robotniczego, po 1939 roku więzień sowieckich łagrów, a następnie żotnierz armii Władysława Andersa - który ironizowat, że odezwy pisarki, gdzie „mówi się o «orłach piastowskich», o «piastowskiej tradycji»”, sprawiają wrażenie, iż „pisuje je nie członek Sowieckiej Partii Komunistycznej, ale jakiś zajadły polski nacjonalista, który świeżo wylazł z kruchty. Nawet polscy nacjonaliści sprzed wojny, tzw. Oenerowcy, bledną przy tej furii nacjonalizmu" (Czuchnowski, 1945, s. 9). 
w Polsce przyszłości. Jednak jej kariera polityczna miała się nieszczególnie układać również w ZSRR po tym, jak „Stalin odstawił ją na boczny tor”. Pisze o tym Berlingowa, która łączy brak ciekawych ofert ze słabnącym zainteresowaniem Stalina Wasilewską jako kobietą (Berlingowa, 1990, s. 127). I wreszcie kwestia jej trzeciego małżeństwa z ukraińskim pisarzem Aleksandrem Kornijczukiem. Zdaniem Gomułki Wasilewska „wybrała miłośc” i wybrała źle, bo jej związek nie był udany:

„Jak zwykle w takich wypadkach bywa u kobiet - ponad wszystko postawiła swój związek małżeński z Kornijczukiem i uczucia, jakie do niego wówczas żywiła. Myślę, że w latach późniejszych sama żałowała swego wyboru. Ale odwrotu już nie miała. Musiała wypić do końca swój kielich goryczy, który ongiś był dla niej pucharem miłości i osobistego szczęścia" (Gomułka, 1994, ss. 493-494).

Przegrana na każdym polu, osamotniona, miała sobie - zdaniem wspomnianego już Sokorskiego - odebrać życie: wymierzyć „karę” za popełnioną wcześniej „zbrodnię”.

W przytoczonych wspomnieniach spisanych po latach Wasilewska uosabia wszystkie patologie komunizmu, zwłaszcza okresu stalinowskiego. Jako kobieta u władzy symbolizuje komunistyczne odwrócenie porządku społecznego w jego najbardziej fundamentalnych założeniach, czyli ról płciowych. „Nienormalność” komunizmu unaocznia „męski wygląd” Wasilewskiej, o którym rozpisywali się niemal wszyscy pamiętnikarze: jej „sztywna” postawa, „toporne” ruchy, wysoki wzrost, „masywna” sylwetka, niski głos, „, niekobiecy” sposób ubierania się (szczególnie mundur pułkownika Armii Czerwonej) itd. Celował w tych opisach Berling, który kreślił obraz Wasilewskiej jako monstrum, demona:

„Widziałem przed sobą wysoką, przystojną, masywną kobietę o męskiej sylwetce, raczej zaniedbaną niż schludną, w mundurze, spodniach i kerzowych butach. Zwracały uwagę ręce: duże, męskie dłonie o długich, nienaturalnie w tył wygiętych palcach, bardzo ruchliwych, jakby ciągle czegoś szukających. [...] Dość niezwykłe wrażenie wywołała ostra różnica w kolorze tęczówek oczu. Jedna z nich była brązowa, druga - ciemnozielona. [...] Wszystko to razem budziło uczucie podobne do czujności w obliczu jakiegoś zagrożenia" (Berling, 1991a, ss. 32-33).

Z perspektywy czasu komunista Berling przedstawiał Wasilewską jako wcielenie „błędów i wypaczeń” komunizmu: jej „nietypowa dla kobiety” żądza władzy, ale i „typowo kobieca" próżność odzwierciedlać miały demoralizację stalinowskich elit ${ }^{18}$. W opinii Wata, ekskomunisty, zaangażowanie Wasilewskiej w komunizm - religijne, niemal fanatyczne - było jednak bardzo „kobiece”. Wat pisze o „niezbadanej duszy kobiet fanatycznych, świętych Teres komunizmu, zwłaszcza Pasionarii”, jak nazywa Wasilewską (Wat, 2011, s. 317). Ów irracjonalizm tradycyjnie definiowany jako „kobiecy” i skłonność do „popadania w egzaltację" miały być cechą całych zbiorowości zafascynowanych komunizmem i osobą Stalina.

18 „Demoralizację” stalinowskich elit, których uosobieniem stała się Wasilewska, miało też unaoczniać stawianie interesów prywatnych ponad dobro publiczne. Berling wielokrotnie pisze, że Wasilewska nie była „ideową” komunistką. Uważa, iż przemawiało przez nią pragnienie zaszczytów, pochlebstw oraz korzyści finansowych. Także Dąbrowska kreśli obraz Wasilewskiej opływającej we Lwowie w luksusy, podczas gdy „miljony polskich ludzi gnane były na Sybir”. „Zdradziła lud” - pisze Dąbrowska, oskarżając w jej osobie komunizm o rozbieżność między szczytną teorią (egalitaryzm) a trywialną praktyką (partyjny elitaryzm) (Dąbrowska, 2009, ss. 41-42). 
Za „typowo kobiecą” poczytywano także skłonność Wasilewskiej do uzależniania się od silniejszych, szczególnie zaś od silnych mężczyzn. Ciołkosz pisał wręcz o „nienormalnych" relacjach Wasilewskiej z mężczyznami, przebiegających według schematu sadomasochistycznego: z jednej strony była „zaślepiona miłością” do Stalina (który, jak wynika z wywodu Ciołkosza, miał zastąpić w jej życiu ojca), z drugiej zaś, w relacjach prywatnych „[...] musiała mieć mężczyzn nie dorastających do niej intelektualnie. Sama zwierzała się, że potrafi kochać tylko mężczyzn niżej od niej stojących" (Ciołkosz, 1977, s. 25).

Można dostrzec analogię między wizerunkiem Wasilewskiej, „po kobiecemu zatraconej w miłości" do Stalina, a wizerunkiem Polski pozostającej w relacji zależności od ZSRR - jak przedstawiano te stosunki po 1956 roku. Gomułka doszedł do władzy pod hasłem zmiany tego układu: „odwilż” przyniosła wymianę elit, ale i symboli dawnego porządku. Małgorzata Fidelis zwraca uwagę, że to właśnie po 1956 roku traktorzystka zniknęła z plakatów propagandowych, a jej miejsce zajęła wzywana do domu Irena - bohaterka popularnej w tamtym czasie komedii w reżyserii Jana Fethkego ${ }^{19}$ - znak nowych, „normalnych” czasów (Fidelis, 2010, ss. 203-237). Takie też miejsce Gomułka „wyznaczył” Wasilewskiej: w jego wspomnieniach stała się „kobietą domową”, oddelegowaną do sfery prywatnej na długo przed tym, nim dokonało się to w rzeczywistości.

\section{Wytwarzanie komunizmu - wytwarzanie narodu}

Mówienie o Wandzie Wasilewskiej rodziło i wciąż rodzi pokusę oceniania jej wyborów w oderwaniu od kontekstu. Spojrzenie z dystansu pozycjonuje Wasilewską, unieruchamia w miejscu, którego obszar wyznacza aktualny stan wiedzy historycznej, ale też własne doświadczenia i zaangażowanie biografów-interpretatorów. W tym rozumieniu pisanie biografii Wasilewskiej jest nie tyle pisaniem historii jej życia - życia ukształtowanego w określonych warunkach społecznych i kulturowych, życia jako samoświadomego procesu - ile pisaniem „historii samej”: konstruowaniem pewnej narracji historycznej, w ramach której - i jednocześnie w ramach przyjętej konwencji - „mieści” się życie człowieka jako gotowy, skończony, spójny „produkt” (White, 2000). Unieważnianie kontekstu kształtowania się, rozwijania i modyfikowania życia człowieka skutkuje ujmowaniem go w kategorie pochodzące z porządku innego dyskursu - takiego, który jest obcy danemu człowiekowi; to jak poszukiwanie stałości tam, gdzie zaistniała płynność, konsekwencji i ciągłości tam, gdzie następowała zmiana.

Jestem zdania, że takie zabiegi, które mają na celu uspójnienie biografii jednostki szczególnie jednostki ważnej w historii danej zbiorowości - podejmowane są w odpowiedzi na tożsamościowe poszukiwania wspólnoty: służą wytworzeniu zbiorowej biografii

19 Fidelis nie neguje emancypacyjnej wymowy samego filmu, którego bohaterka na wszystkie możliwe sposoby usiłuje "wyrwać się" z domu i podjąć pracę (nawet wbrew woli męża), jednak jego tytuł uznaje za zapowiedź reakcyjnego zwrotu w polityce władz komunistycznych względem kobiet. W odróżnieniu bowiem od okresu stalinowskiego, którego hasłem była powszechna aktywizacja zawodowa kobiet - wyrwanie ich z domowego zacisza i włączenie w projekt budowy socjalistycznego państwa, „odwilż” charakteryzowała się „wypychaniem” kobiet z rynku pracy, co poza uzasadnieniami ekonomicznymi (jeden z pierwszych powojennych kryzysów) motywowano ideologicznie (powrót do tradycyjnych ról płciowych: polskich, narodowych - jako „odreagowanie” stalinizmu). 
jako koherentnej całości. Zwracałam już uwagę, że pisanie biografii Wasilewskiej jako komunistki było i wciąż jest „wytwarzaniem komunizmu” w Polsce, będącego w szerokiej perspektywie ważnym - jeśli nie najważniejszym w ostatnich dziesięcioleciach - komponentem polskiej zbiorowej tożsamości.

W pierwszych latach Polski Ludowej upatrywano w historii życia Wasilewskiej alegorii zmiany, transformacji polskiego społeczeństwa, ale też śladów rewizji jego wyobrażeń na własny temat: droga córki ministra w pierwszym rządzie II Rzeczypospolitej w kierunku rewolucji proletariackiej miałaby w tym ujęciu obrazować drogę Polski rozwarstwionej klasowo w kierunku Polski równych szans i możliwości. Wasilewska - po wojnie wprawdzie mieszkanka Kijowa i delegatka do Rady Najwyższej ZSRR, ale też częsty honorowy gość w Polsce: wizytatorka warszawskiego placu budowy, autorka odbierająca z drukarni egzemplarze swoich książek, mówczyni na II Światowym Kongresie Obrońców Pokoju w 1950 roku w Warszawie („Minister Hilary Minc i Wanda Wasilewska zwiedzają Warszawę - Trasa WZ”, 1948, „Pokój zwycięży”, 1950, „Wanda Wasilewska wśród drukarzy”, 1952) jawiła się jako „przewodniczka” polskiego społeczeństwa w jego podróży ku nowemu „ja”: antykapitalistycznemu i antyimperialistycznemu. Miało to być „ja” prężne, dynamiczne, nastawione na pracę, samodoskonalenie; „ja” patrzące w przyszłość i odcinające się od swej - niechlubnej, przedwojennej - przeszłości. Wydawane po wojnie w tysiącach egzemplarzy przemówienia, artykuły, utwory literackie Wasilewskiej wzywały Polaków do zbiorowego wysiłku na rzecz wolności i rozwoju, stworzenia nowej polskiej tożsamości opierającej się na innych niż dotychczas wartościach:

„Polska niezależna - nie w krzyku o niezależności, za którego echem odzywał się śmiech Goebbelsa i brzęczały judaszowe srebrniki, ale w istocie swojej, w własnych swoich drogach, w własnej twórczej pracy, własnym swoim rozwoju. Polska silna nie w napuszonej demagogii deklaracyj o potędze, nie w snach o zawojowaniu cudzych ziem; silna nie kratami więzień, drutami kolczastymi Berezy, pacyfikacjami wsi, tępieniem mniejszości narodowych - Polska silna potężną siłą narodu, który buduje swoją przyszłość na fundamencie sprawiedliwości i wiary w swą słuszność, umiłowania wolności, poszanowania prawa, szacunku człowieka dla człowieka, wytężonej rozumnej pracy, zwartości społeczeństwa, rewindykacyj swoich ziem na zachodzie. [...] Naród walczy, naród buduje, naród tworzy sprawiedliwą, wielką, demokratyczną Polskę. [...] Odrodzona, wolna Polska będzie rosła i krzepła trudem robotnika, chłopa i inteligenta, we wspólnej walce z wrogiem i we wspólnej pracy" (Wasilewska, 1945, ss. 117, 119).

A jednak nie da się nie zauważyć, że od zakończenia wojny Wasilewska była wzorcem osobowym dość ostrożnie podsuwanym polskiemu społeczeństwu. Wprawdzie przyjeżdżała do Polski i z ekipą Bolesława Bieruta utrzymywała poprawne czy wręcz dobre stosunki, ale nowa władza, by okrzepnąć, potrzebowała bohaterów tutejszych, niepodważalnie polskich, patriotycznych, niemogących w żaden sposób kojarzyć się z działalnością agenturalną. Według historyka Marcina Zaremby komuniści mieli kłopot z uzyskaniem legitymizacji jako władza rodzima, a nie narzucona przez Związek Radziecki, dlatego 
obficie sięgali po polską symbolikę narodową, a na „ojca narodu” kreowali mało rozpoznawalnego, a przede wszystkim mało kojarzonego ze Stalinem, Bieruta:

„Legitymizacja nacjonalistyczna bardzo często splatała się z budowaniem przez propagandę charyzmatycznego obrazu Bolesława Bieruta. Przedstawiany w tym okresie [w latach 1945-1947 - przyp. AM] jako bezpartyjny uczestniczył we wszystkich ważniejszych uroczystościach patriotycznych, które w owym czasie niemal zawsze zaczynały się od nabożeństwa. Jako główny aktor $w$ «spektaklu władzy» zawsze wchodził na scenę przepełnioną narodowymi rekwizytami” (Zaremba, 2005, s. 143).

W tym sensie Wasilewska - w czasie wojny nieoficjalna reprezentantka polskich spraw za aprobatą Stalina (jako jedyna z polskich działaczy lewicowych w ZSRR miała specjalny telefon bezpośrednio łączący ją z radzieckim przywódcą), ale też główna krytyczka rządu londyńskiego - „nie nadawała się” na zajmowanie eksponowanych stanowisk w powojennej Polsce. Można powiedzieć, że jej decyzja o pozostaniu w ZSRR - prawdopodobnie podjęta w rezultacie walk w łonie lewicy emigracyjnej, a później zapewne i krajowej - była na rękę rozgrywającym w polskiej polityce powojennej: jako polska pisarka mieszkająca na Ukrainie, a zarazem radziecka dyplomatka w służbie idei pokoju stanowiła doskonały, a zarazem bezpieczny symbol polsko-radzieckiej przyjaźni. Zgrabnie ujął jej rolę ukraiński poeta Mykoła Bażan, gdy napisał, że „Wanda Wasilewska jest tęczą łączącą Dniepr i Wisłę" (cyt. za: Syzdek, 1980, s. 308).

Właściwie aż do czasów Edwarda Gierka Wasilewska nie mieściła się w panteonie polskich bohaterów narodowych. Jej radzieckie biografie pióra Heleny Usijewicz i Leonida Wiengierowa nigdy nie zostały przetłumaczone na język polski. Powstały zresztą przede wszystkim z myślą o radzieckim odbiorcy, któremu miały przybliżyć postać polskiej pisarki gotowej włączyć się w (od)budowę „ojczyzny światowego proletariatu”. Wasilewska miała porywać własnym przykładem: komunistki, internacjonalistki i patriotki, kobiety u władzy, partyjnej działaczki dźwigającej odpowiedzialność za sprawy publiczne, ale też swoją literaturą, w której oprócz obrazków budowy nowego, lepszego świata znalazło się miejsce na miłość, przyjaźń, rodzinę. W powieściach Po prostu miłość (1944) oraz Gdy światło zapłonie (1946) pisała bowiem o tym, co absorbowało ludzi po wojnie: jak nauczyć się żyć w warunkach pokoju, jak znaleźć bliskość, akceptację dla okaleczonego ciała i ukojenie dla znękanego umysłu. Odsłaniając indywidualne problemy swoich bohaterów, zarysowując - co ciekawe! - odmienną sytuację kobiet i mężczyzn w nowej rzeczywistości (inne priorytety, potrzeby, pragnienia, ale też odmienne doświadczenie wojny i konsekwencje tej odmienności po wyzwoleniu), Wasilewska nie zapominała jednak zaznaczyć, że siła jednostki płynie ze wspólnoty, że poczucie użyteczności - świadomość, że się pracuje dla wspólnego dobra - może stać się dla człowieka impulsem do przezwyciężania trudności w sferze prywatnej. 0 tym, że zasadą jej własnego życia stało się owo nieustanne splatanie się prywatnego i publicznego, krzyżowanie się osobistego i politycznego, pisała w szkicu autobiograficznym O moich książkach (1964): 
„Mój dom rodzinny był dobrą szkołą - jak najdalszy od mieszczańskiego samozadowolenia i mieszczańskich ideałów, zawsze żyjący sprawami ogólnymi [...]. Moje przekonania poszły dość szybko w innym niż u moich rodziców kierunku, jednakże atmosfera domu rodzinnego, gdzie na pierwszym planie stały właśnie zagadnienia ogólne, a nie osobiste, musiała się odbić na moim życiu. Było jakby samo przez się zrozumiałe, że człowiek powinien interesować się tym, co się wokół niego dzieje, brać w życiu czynny udział" (cyt. za: Syzdek, 1980, ss. 18-19).

Życie i twórczość Wasilewskiej miały pokazywać, że istotą nowego, komunistycznego społeczeństwa jest zerwanie z burżuazyjną zasadą rozdziału między prywatnym i publicznym, a rolą kobiety uczestnictwo w nowym porządku społecznym na równych prawach z mężczyzną (Attwood, 1999; Ilič, 2001). Stąd biografie pisarki minimalizowały osobisty wymiar jej życia lub wkomponowywały go stosownie w opowieść o niej jako o aktywistce, towarzyszce, „mężu stanu”. Rzadko (jeśli w ogóle) znajdziemy w nich informacje o jej życiu intymnym, uczuciach do kolejnych mężów czy córki. Czytamy o jej partnerach raczej jako o „towarzyszach w walce”, złączonych z nią ideą zmieniania rzeczywistości, niż o ludziach, z którymi łączyły ją drobne sprawy dnia codziennego; dowiadujemy się, że bardzo lubiła dzieci i miała na uwadze ich los, ale niewiele znajdziemy informacji o jej relacji z córką itd. Etos „nowej kobiety”, który Wasilewska realizowała, ale i ucieleśniała, określał bowiem, że macierzyństwo i miłość - choć ważne - nie powinny absorbować kobiety do tego stopnia, by wyłączyły ją z życia publicznego.

To spojrzenie na Wasilewską jako na kobietę zmieniało się z czasem, co już sygnalizowałam: kiedy w latach siedemdziesiątych i osiemdziesiątych XX wieku podjęto wysiłek „repolonizacji” Wasilewskiej, wtapianie jej w „ciało narodu” dokonać się miało poprzez wpisywanie jej w tradycyjne kobiece role - realne i fantazmatyczne. Wasilewska - babcia Piotrusia, niezrównana kucharka, ogrodniczka i wędkarka z zamiłowania, ale też Wasilewska - „matka armii polskiej” - to właśnie udomowiona i/ lub uwznioślona kobiecość pomagała „oswoić” komunizm Wasilewskiej, rozmontować najgroźniejsze skojarzenia ze stalinizmem, a tym samym osadzić ją w „panteonie bohaterów” Polski Ludowej coraz wyraźniej zanurzającej się $w$ dyskursie narodowym z jego romantyczną mitologią i patriotyczną symboliką. Silny potencjał symboliczny wpisany w biografię Wasilewskiej ułatwiat „zagospodarowanie” tej postaci w każdych warunkach: wystarczyło „reaktywować” polską, PPS-owską, inteligencką tożsamość Wasilewskiej, „wyciągnąć” społecznikowską i patriotyczną kartę z jej życiorysu, by tak „podretuszowana” komunistyczna ikona dostarczyła władzy symbolicznej legitymacji. Także dystans czasowy sprzyjał mitologizacji biografii Wasilewskiej: zdaniem Zaremby wraz z upływem czasu władza nie potrzebowała już (tak często) sięgać po stare rekwizyty narodowe, gdyż nauczyła się „wytwarzać” własnych bohaterów - takich, którzy łączyli cechy rewolucjonistów i patriotów (Zaremba, 2005, s. 164). Postać Wasilewskiej znakomicie nadawała się do takiej obróbki. Z okazji trzydziestolecia Polskiej Rzeczypospolitej Ludowej pierwszy sekretarz KC PZPR, Edward Gierek, wymieniał Wasilewską jako jednego z czołowych działaczy, którzy w czasie wojny tworzyli zręby nowej, ludowej państwowości (Gierek, 1974, s. 5), a w 1978 roku minister 
obrony narodowej, generał armii Wojciech Jaruzelski, nadał Wojskowemu Instytutowi Historycznemu w Warszawie imię Wandy Wasilewskiej. W trakcie ceremonii odsłonięto tablicę pamiątkową, na której umieszczono napis: „Wojskowy Instytut Historyczny imienia Wandy Wasilewskiej, wybitnej Polki, pisarki, rewolucjonistki - współorganizatorki Pierwszej Dywizji Piechoty im. Tadeusza Kościuszki. W 35 rocznicę Ludowego Wojska Polskiego. 14 maja 1978 roku" (Marcinkowski, 1978, s. 329)²0. Tożsamość Polaków miała się więc konsolidować wokół tej biografii, a nie w kontrze do niej, miała się w niej przeglądać, szukając potwierdzenia obrazu zbiorowego „ja”.

Zamiar ten się nie powiódt, a współczesne „sięganie po komunizm” ma zupełnie inny charakter: jest ono raczej sięganiem po „obce ciało”, w odróżnieniu od którego i w odrzuceniu którego konstytuuje się tożsamość narodu polskiego. W geście uszczelniania własnych granic i uspójniania własnej biografii komunizm jest dziś „wydalany” przez zdrowe ciało narodu, które w ten sposób strzeże swojej integralności i czystości (Douglas, 2007). Współczesna opowieść o Wasilewskiej nie jest więc (bo nie może być) wytwarzaniem wzorca tożsamościowego, ale antywzorca; narracja heroiczna ustępuje tym samym miejsca narracji demonicznej lub w najlepszym przypadku tragicznej. Komunizm pojawia się w niej jako twór obcy, narzucony przemocą i już skompromitowany. Jego elity charakteryzuje bezideowość, demoralizacja, niedecyzyjność, nieautonomiczność, które to cechy w osobie Wasilewskiej ogromnieją za sprawą stereotypowych skojarzeń z tym, co kobiece.

Zwracałam już uwagę, że wiele współczesnych pisarce osób publicznych rozpisywało się o jej (kobiecej) próżności i materializmie, ale też o rozwiązłym stylu życia i wybujałym temperamencie seksualnym ${ }^{21}$ połączonym z upodobaniem do mocnych trunków ${ }^{22}$; akcentowano jej „iście kobiecy” fanatyzm o proweniencji niemal religijnej, ale przede wszystkim brak politycznej podmiotowości: władza, którą sprawowała, miała pochodzić z męskiego nadania. Najbardziej dosłownie ująt to Julian Stryjkowski, kiedy w rozmowie z Piotrem Szewcem powiedział: „Droga jej do komunizmu prowadziła przez wpływ mężczyzn” (Stryjkowski, 1991, s. 164). Te opinie są szczególnie chętnie przywoływane w najnowszych opracowaniach poświęconych Wasilewskiej (i innym komunistkom). W popularnym dziś gatunku „biografii alkowianej”, której istotą jest ukazanie polityki przez pryzmat relacji intymnych, Wasilewska nie jest już „towarzyszką Wandą”, „żołnierzem w walce o wielkie sprawy”, ale „ulubienicą Stalina” (Koper, 2012, s. 33), „zaślubioną Partii”, „kurtyzaną, która robi to samo, co polityk, tyle że ona w buduarze, a on na mównicy" (Słowiński, 2010, s. 131). Za sprawą stereotypowych ujęć miejsca kobiety w kulturze patriarchalnej

20 Autor sprawozdania komentował: „Na całym jej życiu, twórczości literackiej i działalności politycznej szczególnie plastycznie odcisnęły się ogólniejsze prawidłowości losu polskiego, a zwłaszcza losu postępowej polskiej inteligencji. Wyrastała w kręgu niepodległościowej socjalistycznej tradycji. Gorąca miłość do ojczyzny i wielkie wyczulenie na sprawy społeczne, przyjaźń do prostych ludzi i bunt wobec wszelkiej krzywdy i upodlenia sprawiły, że w całej swej działalności pisarskiej i politycznej reprezentowała nurt rewolucyjny, sprawę narodową łączyła ze sprawą społeczną" (Marcinkowski, 1978, s. 330).

21 Wat pisał na przykład, że „Wasilewska była łasa na mężczyzn” (Wat, 2011, s. 290). Z kolei Dąbrowska sugerowała Wasilewskiej promiskuityzm, kiedy pisała o jej „nie wiadomo którym z rzędu mężu” (Dąbrowska, 2009, s. 42).

22 Michał Borwicz wspominał Wasilewską z czasów lwowskich: „Od czasu, gdy została sowieckim dygnitarzem, Wasilewska może i rzeczywiście nie piła. Nie wiem. Ale że do wojny potrafiła nie wylewać za kołnierz, mogę uczciwie zaświadczyć. I o tym także, że miała mocną głowę" (Borwicz, 1963, s. 137). 
komunizm jawi się jako tyleż potworny (kobieta na czele organizacji politycznej zaburza fundamentalny dla tożsamości narodu porządek ról płciowych, dokonuje symbolicznej kastracji), co możliwy do spacyfikowania. Założenie bowiem, że komunistka to nie żadna „towarzyszka”, kobieta równa mężczyźnie, ale zwyczajna „puszczalska”, „metresa”, „pijana dziwka”, pomaga zapanować nad nią, a więc i nad całym systemem, odzyskać władzę, przywrócić na moment zaburzony „naturalny” układ sił (płciowych) w obrębie narodowej wspólnoty ${ }^{23}$.

Znaczące wydaje się również to, że w powstających dziś publikacjach poświęconych Wasilewskiej niezwykle rzadko przywołuje się jej głos. Zamiast Wasilewskiej - jej tekstów publicystycznych, przemówień, utworów literackich, w których komunizm „artykułuje się” jako projekt polityczny, ideowy, tożsamościowy - „mówią” raczej jej współcześni: wrogowie, współpracownicy, obserwatorzy, czasem (zdystansowani) przyjaciele. W ich wypowiedziach powtarzają się określenia stylu pisania i mówienia Wasilewskiej jako sentymentalnego, to znów natchnionego, patetycznego, fanatycznego, jednym słowem - niemożliwego do słuchania/ czytania. Szczęsna wprost dyskredytuje przekaz Wasilewskiej, kiedy mówi: „Choć jej krytykujące sanacyjną Polskę powieści trudno zaliczyć do największych osiągnięć polskiej prozy, jej książek o rzeczywistości sowieckiej czytać nie sposób” (Szczęsna, 2001). Wydaje się jednak, że pod tymi przytykami do stylu kryje się coś więcej: ośmieszenie i/ lub odebranie głosu jednej z głównych polskich agitatorek komunistycznych jest gestem odmówienia legitymacji komunizmowi jako projektowi innej (nienarodowej) tożsamości, innej wizji wspólnoty; jest odebraniem mu prawa do obecności w historii Polski - w zbiorowym polskim projekcie biograficznym. To wymazywanie obecności i głosu jest szczególnie znaczące, gdy dokonuje się w „kobiecym ciele": tak, jak kobiety znikają z historii narodu jako aktywne podmioty, stając się w zamian „symbolicznym upostaciowieniem ciała narodowej wspólnoty” (McClintock, 2004, s. 90), tak komunizm znika jako projekt zmiany stosunków społecznych, stając się symbolem-straszakiem: potworem, który budzi lęk, lub pajacem, który śmieszy.

Wanda Wasilewska nie jest jedyną komunistką, którą w ostatnich latach zainteresowali się biografowie (Fijałkowska, 1995; Shore, 2008; Sobór-Świderska, 2009; Krasucki, 2009). A jednak jest w niej coś szczególnego lub też szczególnie niepokojącego: oto jej sylwetka działaczki nie pasuje do popularnego wyobrażenia czy skryptu polskiego komunisty jako osoby pochodzenia żydowskiego („żydokomuna”), z nizin społecznych, prymitywnej, ciemnej, niewykształconej (Legutko, 2008); „obcego”, który od zawsze tkwił w ciele narodu niczym ropiejący wrzód, czekając na perforację, bądź też „obcego”, który został „wszczepiony” w owo ciało, „wsączony” w nie. W wielu punktach historia jej życia

23 Tytuł książki Sławomira Kopra Kobiety władzy PRL (2012) jednoznacznie wskazuje, że komunistek nie traktuje się dziś podmiotowo. W publikacji autor pokazuje takie działaczki, jak Wanda Wasilewska, Julia Brystygierowa czy Małgorzata Fornalska, nie jako kobiety u władzy, decydentki polityczne, sprawczynie bądź niezależne uczestniczki ważnych wydarzeń, ale właśnie kobiety władzy, a więc takie, które utrzymywały kontakty (przede wszystkim seksualne) z mężczyznami sprawującymi wysokie funkcje publiczne (na przykład Małgorzata Fornalska, ps. Jasia - jedna z ważniejszych postaci Polskiej Partii Robotniczej, zamordowana przez gestapo w lipcu 1944 roku - stała się bohaterką rozdziału zatytułowanego Wszystkie kobiety Bolesława Bieruta). Wpisane w relacje rodzinne i/ lub miłosne, komunistki przestają być samodzielnymi aktorkami życia publicznego: nie widzimy w nich polityczek i działaczek partyjnych, ale wyłącznie żony/ siostry/ córki/ kochanki polityków i działaczy. 
i aktywności odstaje od tego „modelu”, a wręcz go rozsadza: ujawnia, że komunizm jako projekt polityczny, ideowy i tożsamościowy trafił na przedwojenne salony, rozprzestrzenił się w środowisku elit, nawet tych szczególnie zasłużonych dla Polski. Wasilewska była przecież córką ministra, współtwórcy Legionów, przyjaciela Piłsudskiego; świetnie wykształcona (miała doktorat z filozofii), obyta, kulturalna i mimo różnych trudności zawodowych nie przymierała głodem. W dodatku działała w PPS, a nawet zasiadała w jej władzach. Co zatem pchnęło ją do zaangażowania się w komunizm? Z czym wiązała się jej decyzja, z jakimi wyborami prywatnymi i publicznymi? Czy jej przykład mógł być „zaraźliwy", a więc groźny dla narodowej wspólnoty?

Współczesne próby demonizowania i/ lub ośmieszania komunizmu wykluczają myślenie o nim jako o projekcie szeroko zakrojonych zmian, w tym o charakterze tożsamościowym: (s)konstruowanym, (wy)tworzonym w określonych warunkach społecznych i kulturowych, rozwijającym się, podlegającym przemianom; projekcie aktualizowanym i modyfikowanym pod wpływem różnych czynników. Eliminują też myślenie o komunizmie jako o formie transgresji, przekroczenia tożsamościowych granic, wykroczenia poza normy - płciowe, seksualne, klasowe, religijne - obowiązujące w obrębie wspólnoty narodowej i rodzinnej; projekcie rewolucyjnym, niebezpiecznym, i - co ważne - możliwym.

Tymczasem pisma Wasilewskiej - jej listy, artykuły, powieści, przemówienia, szkice autobiograficzne - są właśnie świadectwem rozłożonego w czasie dojrzewania do komunizmu jako projektu sprawiedliwości społecznej, pracy na rzecz wspólnego dobra, walki z nierównościami, egalitaryzmu, emancypacji grup wykluczonych i zmarginalizowanych, pojmowanych w kategoriach ponadnarodowych. Byt to projekt o proweniencji romantycznej (walka, rewolucja) i zarazem pozytywistycznej (codzienna, żmudna praca), wznoszony na fundamencie idei wolności, równości, braterstwa, a zarazem mocno osadzony w kontekście społecznym i ekonomicznym: wyrosły z rozczarowania rzeczywistością Polski międzywojennej, postrzeganej jako kapitalistyczna, ksenofobiczna, imperialistyczna24.

„Moje wczesne dzieciństwo upłynęło w atmosferze marzeń o wolnej, niepodległej Polsce. [...] Jaka będzie ta niepodległa Polska - to stało na dalszym planie, mgliście i niejasno rozumiało się jakby samo przez się, że będzie wolna i sprawiedliwa dla wszystkich. Wychowywałam się na romantycznej literaturze, na wierszach mówiących o walce o wolność, na tradycji polskich powstań, na książkach mówiących o walce z caratem, z Prusakiem, na głębokiej wierze, że ten kraj wyzwolony stanie się rajem dla wszystkich jego mieszkańców. Przyszedł 1918 rok. W wyniku pierwszej wojny światowej, obalenia caratu przez rewolucję powstało państwo polskie, przez sto dwadzieścia z górą lat pozbawione samoistnego bytu. I od razu obnażyto swe klasowe oblicze. Było państwem kapitalistycznym, zależnym w dodatku od obcych kapitałów, z wszystkimi wypływającymi stąd następstwami. Przepaść między marzeniami i rzeczywistością była jasna nawet dla oczu dziecka. I dlatego mając trzynaście, czternaście lat chodziłam na robotnicze zgromadzenia i demonstracje i od pierwszego roku uniwersytetu byłam członkiem młodzieżowej organizacji socjalistycznej” (Wasilewska, 1983, s. 16).

24 W rozmowie z Torańską mówił też o tym Berman: „Cel jednak był zawsze ten sam: stworzyć inną Polskę, jednolitą narodowościowo, bez analfabetyzmu, bardzo uprzemysłowioną, o wysokim poziomie cywilizacyjnym, rozwiniętej kulturze, umożliwiającą awans społeczny milionom ludzi. Tak ją sobie wyobrażaliśmy. Taką mieliśmy wizję" (Torańska, 2012, s. 101). 
Wasilewska była gorącą orędowniczką tego projektu, „bardem rewolucji”, której pozostała wierna nawet wtedy, gdy ta poszła swoim - innym niż zakładano - torem. W liście do Janiny Broniewskiej pisała w latach pięćdziesiątych ubiegłego wieku:

„[...] widziałam na własne oczy, jak setki i tysiące ludzi mieszkają i żyją w epoce komunizmu i to nie na księżycu, ale o marne tysiąc kilometrów od Kijowa, w Dniepropietrowskiej i Chersonskiej «obłasti», o czym ze skruchą wyznaję, tuziemiec, nie miałam pojęcia. I to wszystko od fundamentów domków rodzinnych aż po gmaszyska elektrowni jest nowe i jak z igły, liczy sobie cztery lata, a po trzy i dwa i rok życia, i wyrosło jak grzyby po deszczu, i rośnie, i rozprzestrzenia się z błyskawiczną szybkością. Jak o tym napisać? Co z tego zrobić, bo ci przecie i tak nikt nie uwierzy, i powie, żeś stara, zaślepiona wariatka" (Zatorska, 1976, ss. 186-187).

Nie ma tu miejsca na szczegółową analizę założeń tego projektu, lecz jedno warto podkreślić: chociaż zręby myślenia Wasilewskiej uformowały się w domu rodzinnym, niepodległościowym i socjalistycznym, jej dojrzewanie do samodzielnej działalności wiązało się z odejściem od rodzinnej tradycji. „Między nami był cichy układ - nie będziemy rozmawiać na tematy polityczne, bo wiedzieliśmy, że dojdzie do nieodwołalnego zerwania" - mówiła o ojcu (Wasilewska, 1968, s. 133). Komunizm był więc dla niej nie tylko ideą polityczną, ale też projektem nowych relacji intymnych, rodzinnych, miłosnych, macierzyńskich itd. Była w tym myśleniu „typowa” dla swojego pokolenia, co pokazała książka Marci Shore Kawior i popiół, a zarazem „nieoczywista”, choćby z uwagi na to, jak ją wychowano i czego się po niej spodziewano. Jej nazwisko zobowiązywało przecież: jako „córka Leona”, „polska Wanda”, powinna była równie mocno nienawidzić Rusa, co Niemca, szukać rozwiązań problemów społecznych bez odrzucania wartości nadrzędnych, takich jak ojczyzna, patriotyzm, naród. A jednak jako komunistka, a później obywatelka ZSRR, uczyniła siebie „obcą”: „wyobcowała” się z dominującego wzorca tożsamości narodowej na długo przedtem, zanim sam naród uznał ją za „renegatkę”. Swoim życiem i twórczością wskazywała, że takie kategorie, jak naród, patriotyzm, ojczyzna wymagają przedefiniowania, jeśli mają pomieścić możliwie dużo grup społecznych, interesów i doświadczeń: „[...] zaczęłam rozumieć, że «naród» to nie jest jakaś jednolita całość [...], że w owym «narodzie» są dwa obozy, między którymi nie może być żadnego porozumienia. Jeden to robotnicy i chłopi, drugi - to ci, którzy robotników i chłopów wyzyskują i nienawidzą" (Wasilewska, 1975, ss. 1, 8). Natomiast jako kobieta miała wśród komunistów odnaleźć to, czego nie znalazła gdzie indziej - uznanie dla „towarzyszki”, samodzielnej działaczki, „Pasionarii”, nie zaś wyłącznie: „córki Leona”. „Kiedy ojciec zmarł [w grudniu 1936 roku - A.M.], wówczas, kiedy byłam całkowicie dorosłym człowiekiem, towarzysze, komuniści - którzy do niego mieli zupełnie określony stosunek - przynieśli kwiaty na trumnę mojego ojca z napisem: «Ojcu Wandy»" (Wasilewska, 1968, s. 133).

Komunizm Wasilewskiej jako projekt tożsamości transgresyjnej wciąż czeka na swojego biografa lub biografkę ${ }^{25}$.

25 Zarys tego projektu kreślę w artykule Komunistki i duch transgresji. „Przypadek” Wandy Wasilewskiej (Mrozik, 2013). 


\section{Bibliografia}

Attwood, L. (1999). Creating the New Soviet Woman. Women's Magazines as Engineers of Female Identity, 1922-53. New York: Palgrave Macmillan.

Berling, Z. (1991a). Wspomnienia: Przeciw 17 Republice. Warszawa: Polski Dom Wydawniczy.

Berling, Z. (1991b). Wspomnienia: Wolność na przetarg. Warszawa: Polski Dom Wydawniczy.

Berlingowa, M. (1990). Bliżej prawdy. Warszawa: Zetpress.

Bonnell, V. E. (1997). Iconography of Power. Soviet Political Posters under Lenin and Stalin. Berkeley: University of California Press.

Borwicz, P. (1963). „Inżynierowie dusz”. Zeszyty Historyczne, (3), 121-163.

Bourdieu, P. (1986). L'illusion biographique. Actes de la recherche en sciences sociales, 62(1), 69-72. doi:10.3406/arss.1986.2317

Brzóstowicz-Klajn, M. (2004). Nowego człowieka obraz. W Z. Łapiński \& W. Tomasik (Red.), Słownik realizmu socjalistycznego (ss. 147-152). Kraków: Universitas.

Chmielewska, K., Mrozik, A., \& Wołowiec, G. (Red.). (2013). PRL - życie po życiu. Warszawa: Instytut Badań Literackich PAN.

Chruszczow, N. (2000). Fragmenty wspomnień. Zeszyty Historyczne, (132), 109-192.

Ciołkosz, A. (1977). Wanda Wasilewska. Dwa szkice biograficzne. London: Polonia Book Fund Ltd.

Čolović, I. (2001). Polityka symboli. Eseje o antropologii politycznej. (M. Petryńska, Tłum.). Kraków: Universitas.

Czuchnowski, M. (1945). Z Moskwy do... Moskwy. London: Biblioteka Walczącej Polski.

Dąbrowska, M. (2009). Dzienniki. 1914-1965 (T. 10 (1956-1957)). Warszawa: PAN.

Douglas, M. (2007). Czystość i zmaza. Analiza pojęć nieczystości i tabu. (M. Bucholc, Tłum.). Warszawa: PIW.

Fidelis, M. (2010). Women, Communism, and Industrialization in Postwar Poland. New York: Cambridge University Press.

Fijałkowska, B. (1995). Borejsza i Różański: przyczynek do dziejów stalinizmu w Polsce. Olsztyn: Wyższa SzkoŁa Pedagogiczna.

Gierek, E. (1974). Socjalizm wprowadził Polskę w nurt postępu dziejowego. Wojskowy Przegląd Historyczny, (3 (70)), 3-17.

Gomułka, W. (1994). Pamiętniki (T. 2). Warszawa: Polska Oficyna Wydawnicza „BGW”.

Hobsbawm, E. (1978). Man and Woman in Socialist Iconography. History Workshop Journal, 6(1), 121-138. doi:10.1093/hwj/6.1.121

Hobsbawm, E., \& Ranger, T. (Red.). (2008). Tradycja wynaleziona. (M. Godyń \& F. Godyń, Tłum.). Kraków: Wydawnictwo Uniwersytetu Jagiellońskiego.

Ilič, M. (Red.). (2001). Women in the Stalin Era. New York: Palgrave Macmillan.

Janion, M. (2006). Polonia powielona. W M. Janion, Niesamowita Słowiańszczyzna. Fantazmaty (ss. 259-299). Kraków: Wydawnictwo Literackie.

Janowski, W. (1996). Niepublikowane fragmenty wspomnień Wandy Wasilewskiej z lat 1939-1945. Teki Archiwalne. Seria nowa, 1 (23), 131-138.

Koper, S. (2012). Kobiety władzy PRL. Warszawa: Czerwone i Czarne.

Krasucki, E. (2009). Międzynarodowy komunista. Jerzy Borejsza - biografia polityczna. Warszawa: PWN.

Kuncewicz, P. (1995). Leksykon polskich pisarzy współczesnych (T. 2). Warszawa: Graf-Punkt. 
Kusiak, A. (2006). Narodowa pamięć historyczna a historia kobiet. W M. Gabryś, M. Rudaś-Grodzka, \& B. Smoleń (Red.), Polka. Medium, cień, wyobrażenie (ss. 214-217). Warszawa: Centrum Sztuki Współczesnej; Fundacja Odnawiania Znaczeń.

Legutko, R. (2008). Esej o duszy polskiej. Warszawa: Ośrodek Myśli Politycznej.

Marcinkowski, A. (1978). Uroczystość nadania Wojskowemu Instytutowi Historycznemu imienia Wandy Wasilewskiej. Wojskowy Przegląd Historyczny, (2 (84)), 328-332.

McClintock, A. (2004). „No Longer in a Future Heaven”: Gender, Race and Nationalism. W A. McClintock, A. Mufti, \& E. Shohat (Red.), Dangerous Liaisons. Gender, Nation and Postcolonial Perspectives (ss. 89-112). Minneapolis: University of Minnesota Pros.

Minister Hilary Minc i Wanda Wasilewska zwiedzają Warszawę - Trasa WZ. (1948). Polska Kronika Filmowa, (47). Pobrano z http://www.youtube.com/watch?v=bKFr-EBISYs

Mrozik, A. (2013). Komunistki i duch transgresji. „Przypadek” Wandy Wasilewskiej. Teksty Drugie, (3 (141)).

Niemiec, E. (2011, wrzesień 14). Akuszerka PRL-u. Dziennik Polski. Pobrano z http://m.e-dp.pl/pl/warto-wiedziec/kurier-galicyjski/1173055-akuszerka-prl-u.html

Pickhan, G. (2008). Wanda Wasilewska: Bilder und Selbstbilder nach dem Zweiten Weltkrieg. W C. Kraft (Red.), Geschlechterbeziehungen in Ostmitteleuropa nach dem Zweiten Weltkrieg (ss. 87-102). München: Oldenbourg.

Pokój zwycięży. (1950). WFDiF. Pobrano z http://www.youtube.com/watch?v=Lyn2j86xTqc

Pryhara, M. (1982). Wieloletnia współpraca. W E. Syzdek (Red.), Wanda Wasilewska we wspomnieniach (ss. 187-190). Warszawa: Książka i Wiedza.

Putrament, J. (1953). Wanda Wasilewska i rewolucyjny nurt literatury polskiej. W J. Putrament, Na literackim froncie (ss. 9-15). Warszawa: Czytelnik.

Radzymińska, J. (b.d.). Dzienniki z lat 1945-1991. T. 11 (1982-1983). Rkp. BN, sygn. akc. 13710.

Shore, M. (2008). Kawior i popiót. Życie i śmierć pokolenia oczarowanych i rozczarowanych marksizmem. (M. Szuster, Tłum.). Warszawa: Świat Książki.

Słowiński, P. (2010). Boginie zła, czyli kobiety okrutne, żądne władzy i występne. Katowice: Videograf II.

Smołycz, J. (1982). Organiczny stop motywów. W E. Syzdek (Red.), Wanda Wasilewska we wspomnieniach (ss. 191-211). Warszawa: Książka i Wiedza.

Sobór-Świderska, A. (2009). Jakub Berman. Biografia komunisty. Warszawa: IPN.

Sokorska, M. (1982). Kobieta o wielkim sercu. W E. Syzdek (Red.), Wanda Wasilewska we wspomnieniach (ss. 141-144). Warszawa: Książka i Wiedza.

Stryjkowski, J. (1991). Ocalony na Wschodzie. Montricher: Les Editions Noir sur Blanc.

Syzdek, E. (1975). O Wandzie Wasilewskiej. Nowe Drogi, (7), 74-86.

Syzdek, E. (1979). Wanda Wasilewska (1905-1964). Warszawa: Wydawnictwo MON.

Syzdek, E. (1980). W jednym życiu tak wiele. Warszawa: Młodzieżowa Agencja Wydawnicza.

Syzdek, E. (1981). Działalność Wandy Wasilewskiej w latach drugiej wojny światowej. Warszawa: Wydawnictwo MON.

Syzdek, E. (Red.) (1983). Deklaracja ideowa Związku Patriotów Polskich. Lublin: Wydawnictwo Lubelskie.

Szczęsna, J. (2001, marzec 23). Wanda Wasilewska: Bywszaja Polka. Gazeta Wyborcza. Pobrano z http:// wiadomosci.gazeta.pl/kraj/1,34311,192981.html

Toniak, E. (2008). Olbrzymki: kobiety i socrealizm. Kraków: Korporacja Ha!art.

Torańska, T. (2012). Oni. Warszawa: Ringier Axel Springer Polska Sp. z o.o. 
Trznadel, J. (1998). Kolaboranci. Tadeusz Boy-Żeleński i grupa komunistycznych pisarzy we Lwowie 1939-1941. Komorów: Wydawnictwo Antyk.

Usievich, E. (1953). Vanda Vasilevskaia: kritiko-biograficheskiĬ ocherk. Moskva: SovetskiǏ pisatel’.

Vengerov, L. (1955). Vanda Vasilevskaia: kritiko-biograficheskiI ocherk. Moskva: Goslitizdat.

Wanda Wasilewska wśród drukarzy. (1952). Polska Kronika Filmowa, (21). Pobrano z http://www.youtube. com/watch?v=N3M3RliqBKk

Wasilewska, W. (1945). Płomień i próchno. Zbiór artykułów i przemówień. Moskwa: Związek Patriotów Polskich.

Wasilewska, W. (1968). Wspomnienia Wandy Wasilewskiej. Z pola walki, (1 (41)), 115-195.

Wasilewska, W. (1975). Lata, które minęły (I). Argumenty, (21).

Wasilewska, W. (1982). Wspomnienia Wandy Wasilewskiej (1939-1944). Archiwum Ruchu Robotniczego, 7 , 339-432.

Wasilewska, W. (1983). Podróż po życiu i książkach (I). Tu i Teraz, (1).

Wat, A. (2011). Mój wiek. Pamiętnik mówiony (T. 1). Kraków: Universitas.

White, H. (2000). Poetyka pisarstwa historycznego. (E. Domańska \& M. Wilczyński, Tłum. \& Red.). Kraków: Universitas.

Zaremba, M. (2005). Komunizm, legitymizacja, nacjonalizm. Nacjonalistyczna legitymizacja władzy komunistycznej w Polsce. Warszawa: Wydawnictwo TRIO.

Zatorska, H. (1976). Wanda Wasilewska. Warszawa: Wydawnictwa Szkolne i Pedagogiczne.

Zawiśliński, S. (1991). Wyznania zdrajcy. Wywiad-rzeka z Włodzimierzem Sokorskim. Chicago, Warszawa: Andy GraFik Ltd.

Zwoliński, S. (Red.). (2003). Wojsko polskie w ZSRR w 1943 roku wobec powstającego systemu władzy. Udziat 1. Dywizji Piechoty im. Tadeusza Kościuszki w bitwie pod Lenino. Warszawa: Neriton.

\section{Communists have no homeland: a portrait of Wanda Wasilewska}

Abstract: The paper offers an analysis of a number of biographies of Wanda Wasilewska, written in different historical periods. An attempt was made to reconstruct the mechanisms that governed the functioning of Wanda Wasilewska's communist figure in the Polish political discourse; explain how she was perceived by the society, and how it altered in the course of the Polish cultural and historical transformations. A biography of an individual gains coherence as a result of the community's search for its identity: it serves as a building block for a coherent biography of the entire community. The writing and rewriting of the biography of Wasilewska has long been a kind of "production of communism" in Poland, and communism has been one of the most important aspects of Polish identity in the recent decades.

Keywords: communism, biography, patriotism, identity, nation, discourse analysis, Wanda Wasilewska 